Historic, Archive Document

Do not assume content reflects current scientific knowledge, policies, or practices. 



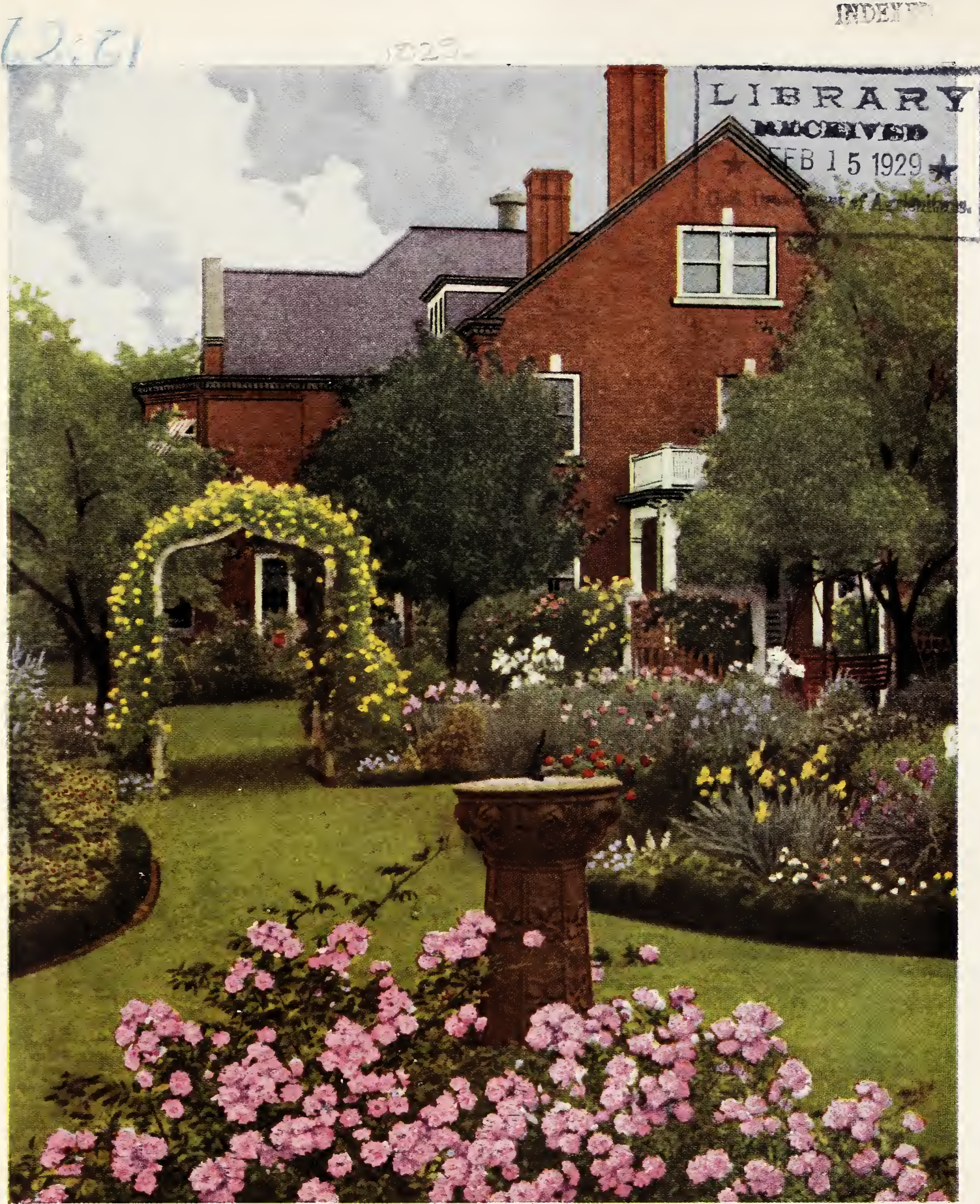

Bed of Tausendschon or Thousand Beauties Roses.

\section{Our Lawn and Garden Specialties}

\section{William C. Moore \& Company}

Growers of High Grade Nursery Stock

Dept. L NEWARK, NEW YORK STATE 


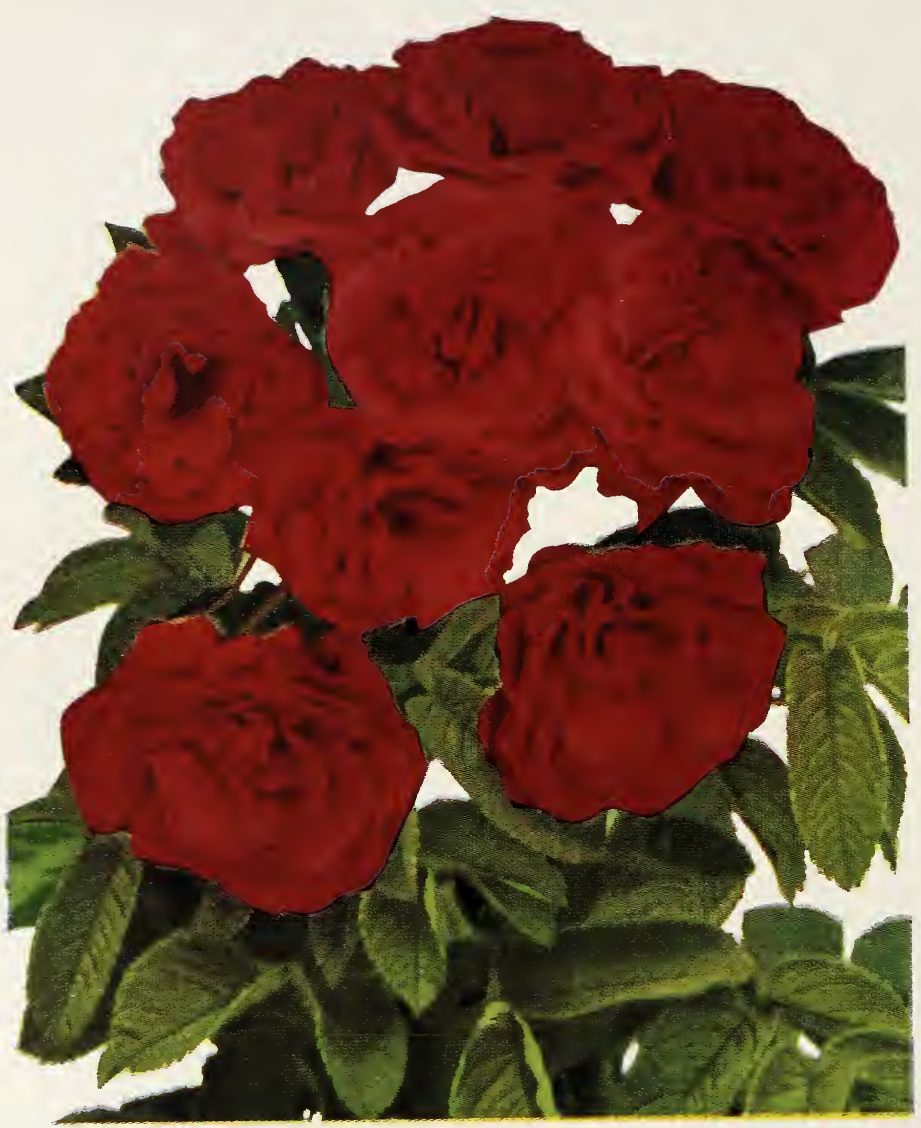

\section{F. J. \\ Grootendorst}

\section{A New Rugosa Rose of Exceptional Merit}

A new Hybrid Rugosa. True Rugosa foliage; blooms bright crimson, in clusters, blooming from early Spring to frost; strong but compact. Particularly suitable for hedging and mass planting. Distinct, different, the only one of its kind.

We recommend it highly.

$\begin{array}{rr}\text { XXX Size only...\$r.75 } & \text { Doz. } \\ \$ 20.00\end{array}$

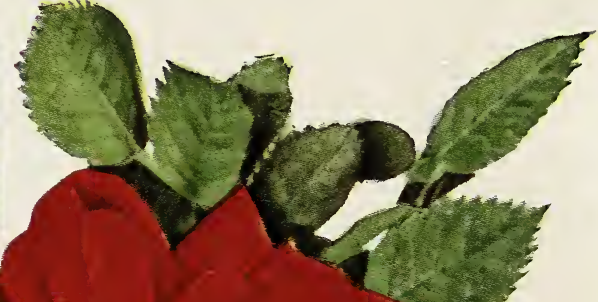

\section{Paul's Scarlet}

A new hardy Rose of the most vivid, bright red in any Climbing Rose. Blooms in clusters of half double flowers which are conspicuous for both size and brilliance. Very hardy. Should be in every garden.

XXX Size (extra large size) $\$ 2.00$ each; $\$ 23.00$ per dozen.

XX Size (large size). \$I.75 each; \$20.00 per dozen.

$\mathrm{X}$ Size (medium size). \$r.35 each; \$15.00 per dozen.

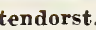




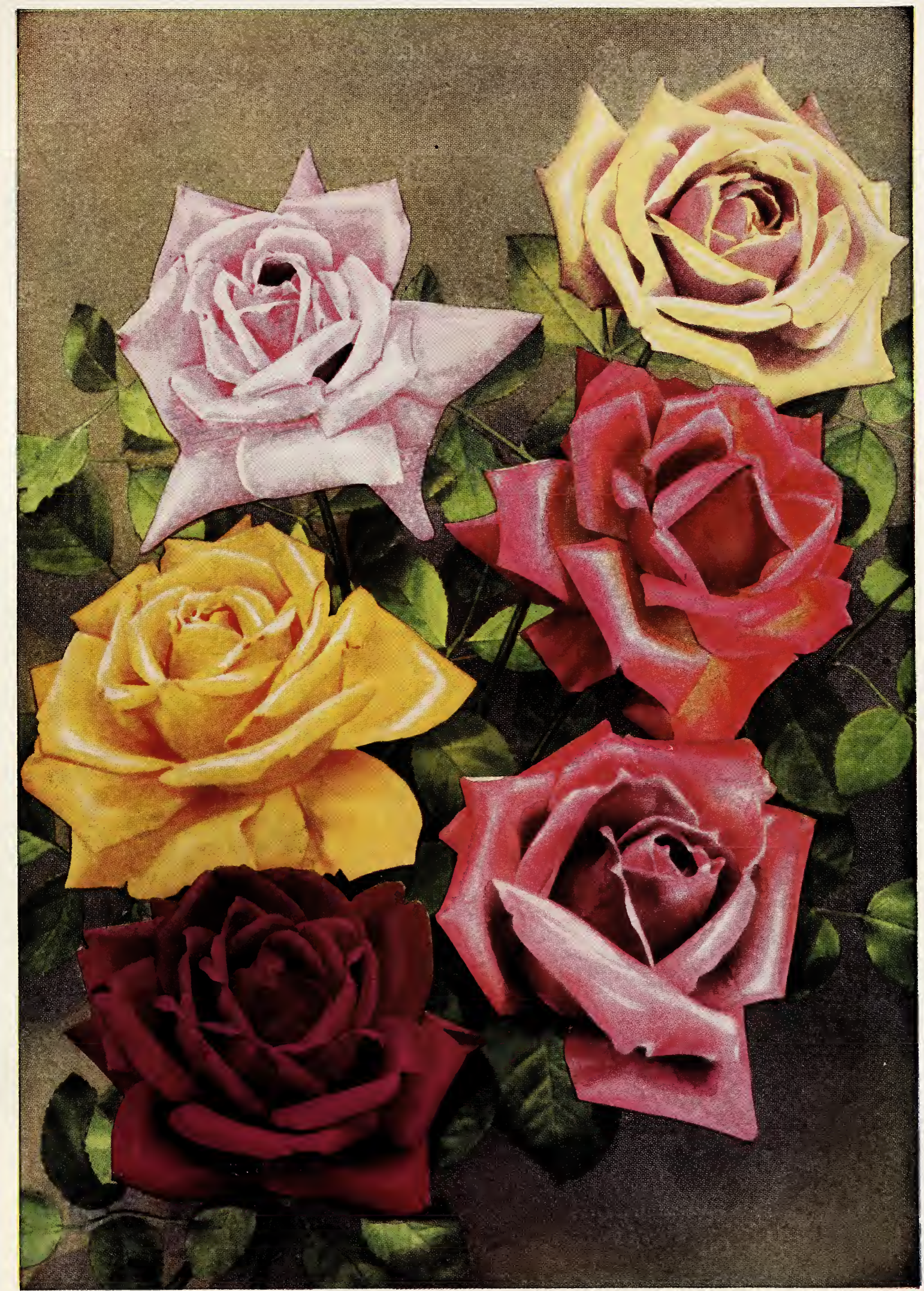

Iadam Caroline Testout (Top) Duchess of Wellington (Middle)
Edward Mawley (Bottom)

Ophelia (Top) Mme. Edouard Herriot (Middle)

Radiance (Bottom)

One each of the above six (XXX size) for \$10.50. This Group offered for Spring delivery, and in the XXX size only. 


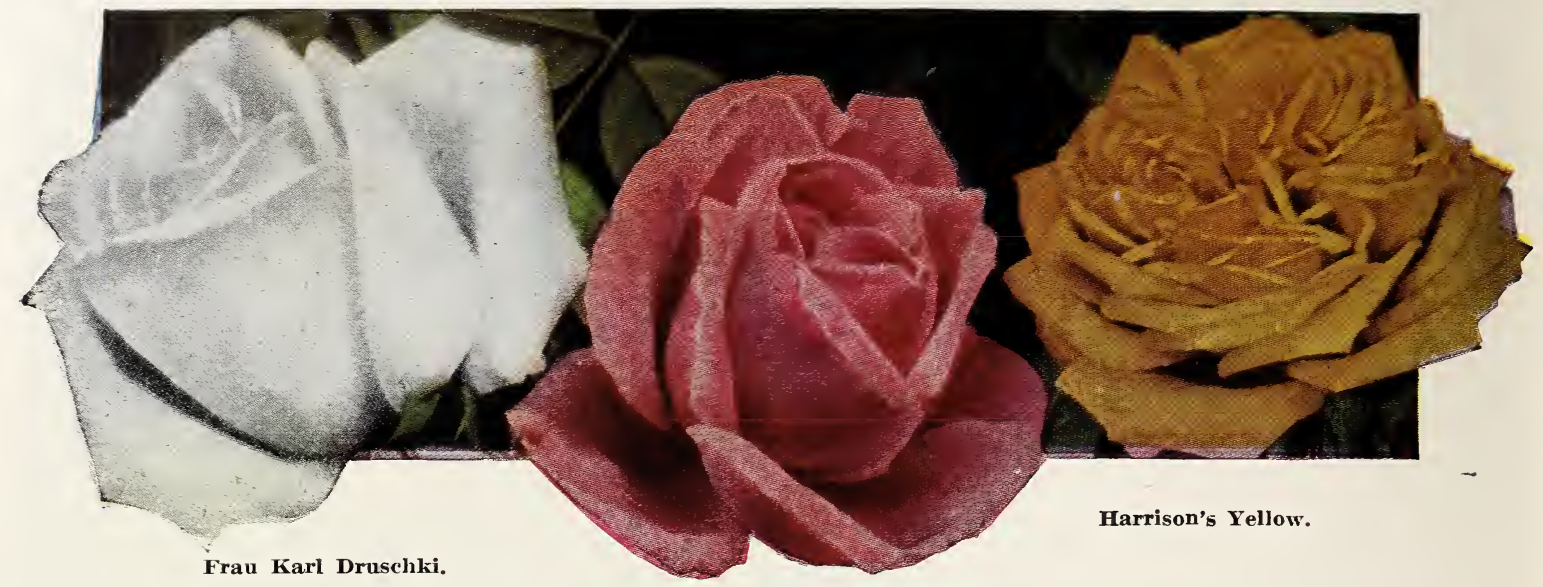

Mrs. John Laing.

The three above (one of each) in XXX Size for only...........\$5.00

The three above (one of each) in XX Size for only.................25

The three above (one of each) in $X$ Size for only............... 3.75
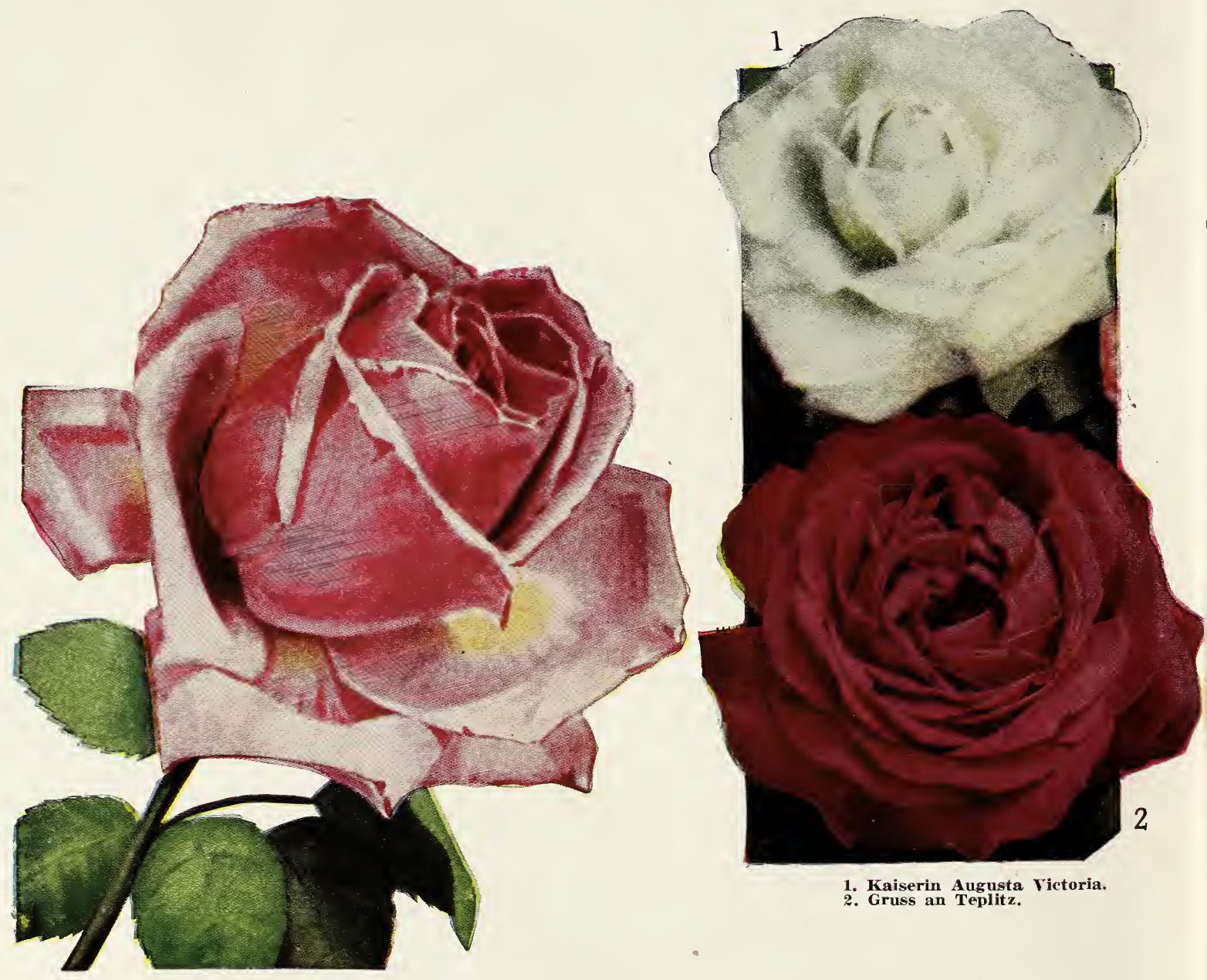

1. Kaiserin Augusta Victoria. 2. Gruss an Teplitz.

Jonkheer J. L. Mock.

$\$ 2.00$ each; $\$ 23.00$ per dozen, offered in XXX Size and for Spring delivery only.
The two in XXX Size for. $\$ 3.50$

The two in XX Size for. 3.00

The two in $X$ Size for.. 2.50 


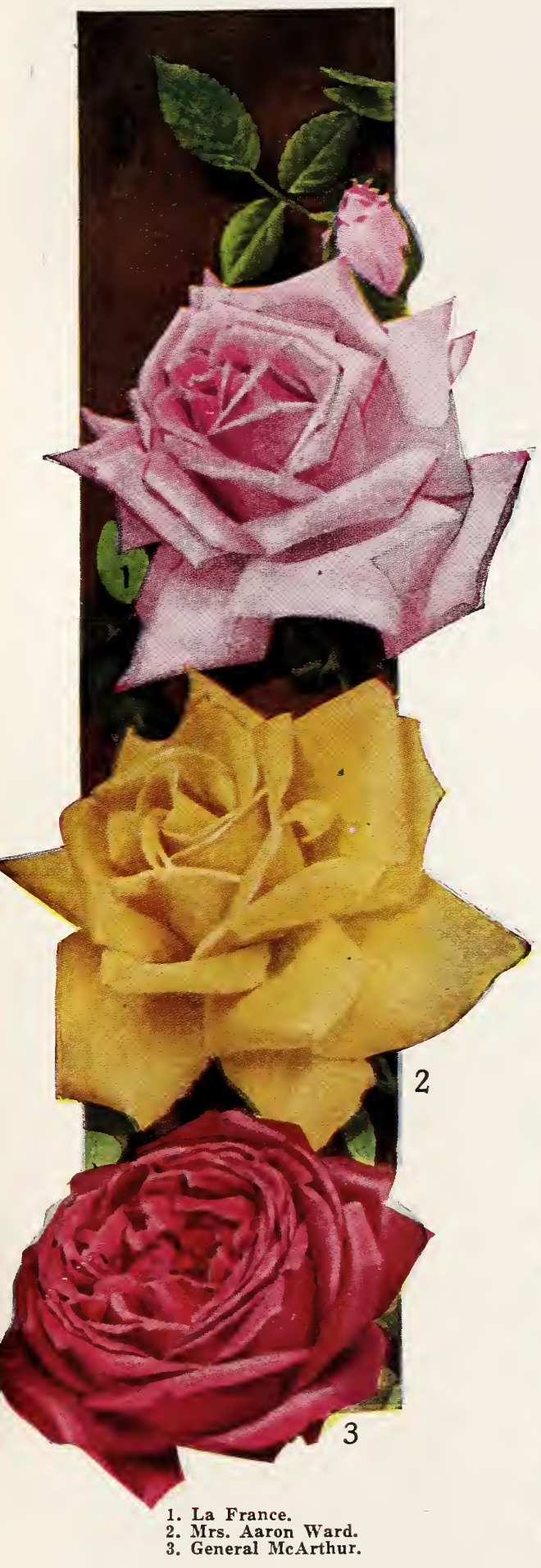

The above three (one of each) for $\$ 5.50$, offered in XXX Size and for Spring delivery only.

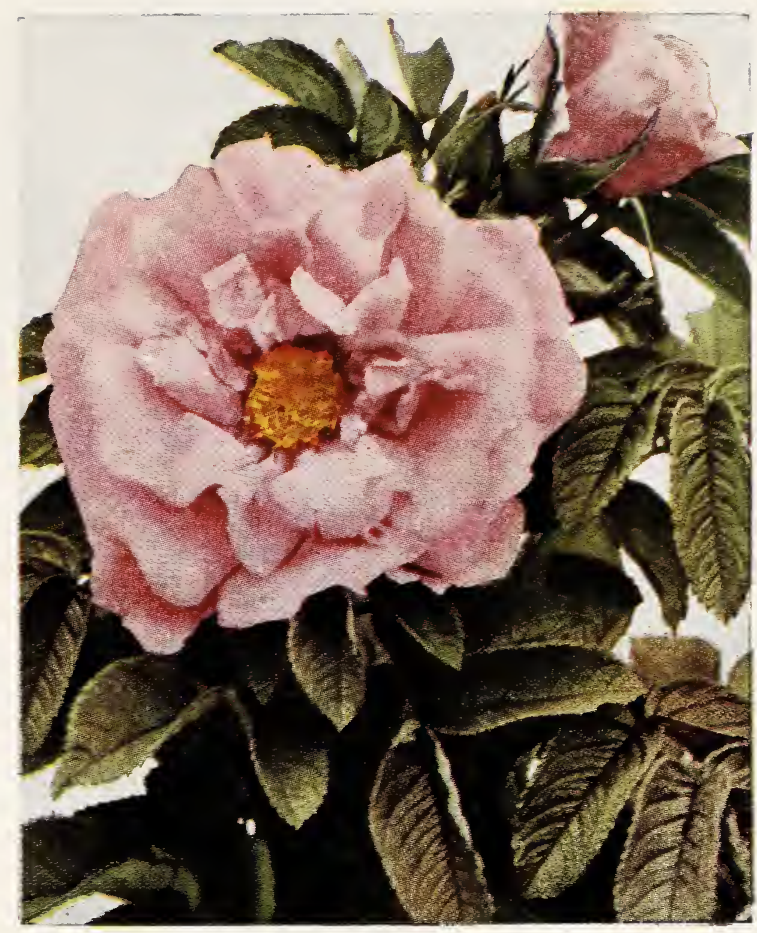

Rugosa Rose, Conrad F. Meyer.
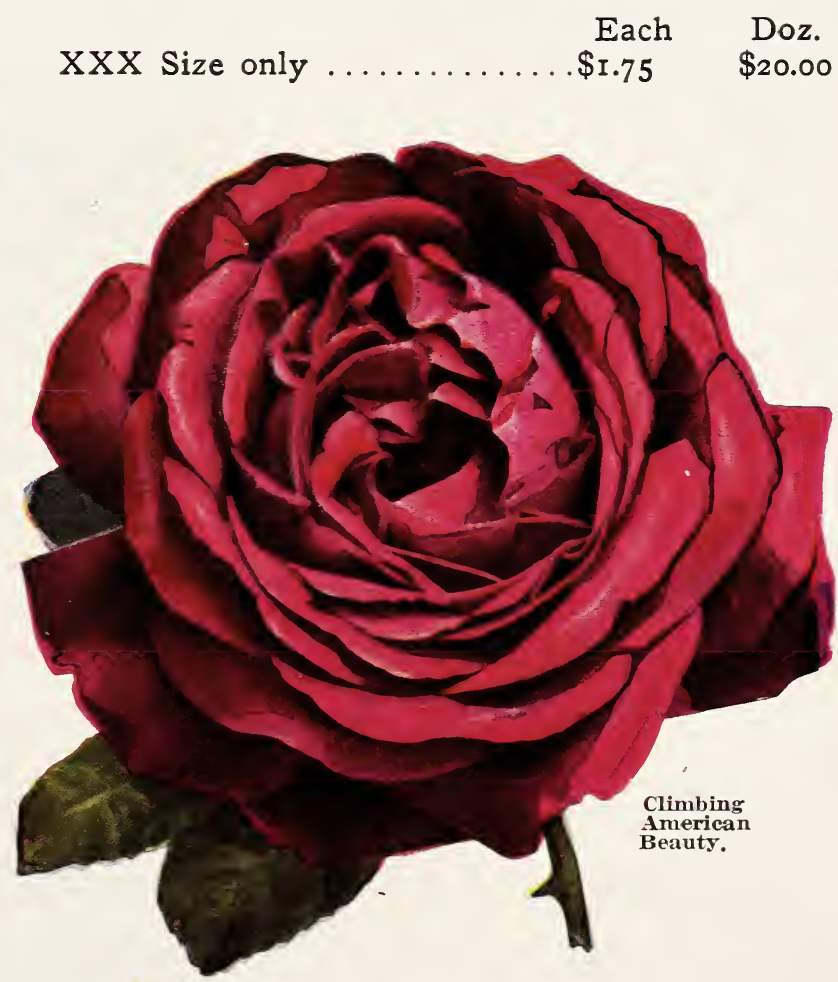

Each

Doz.

$\$ 22.00$

20.00

I 5.00 


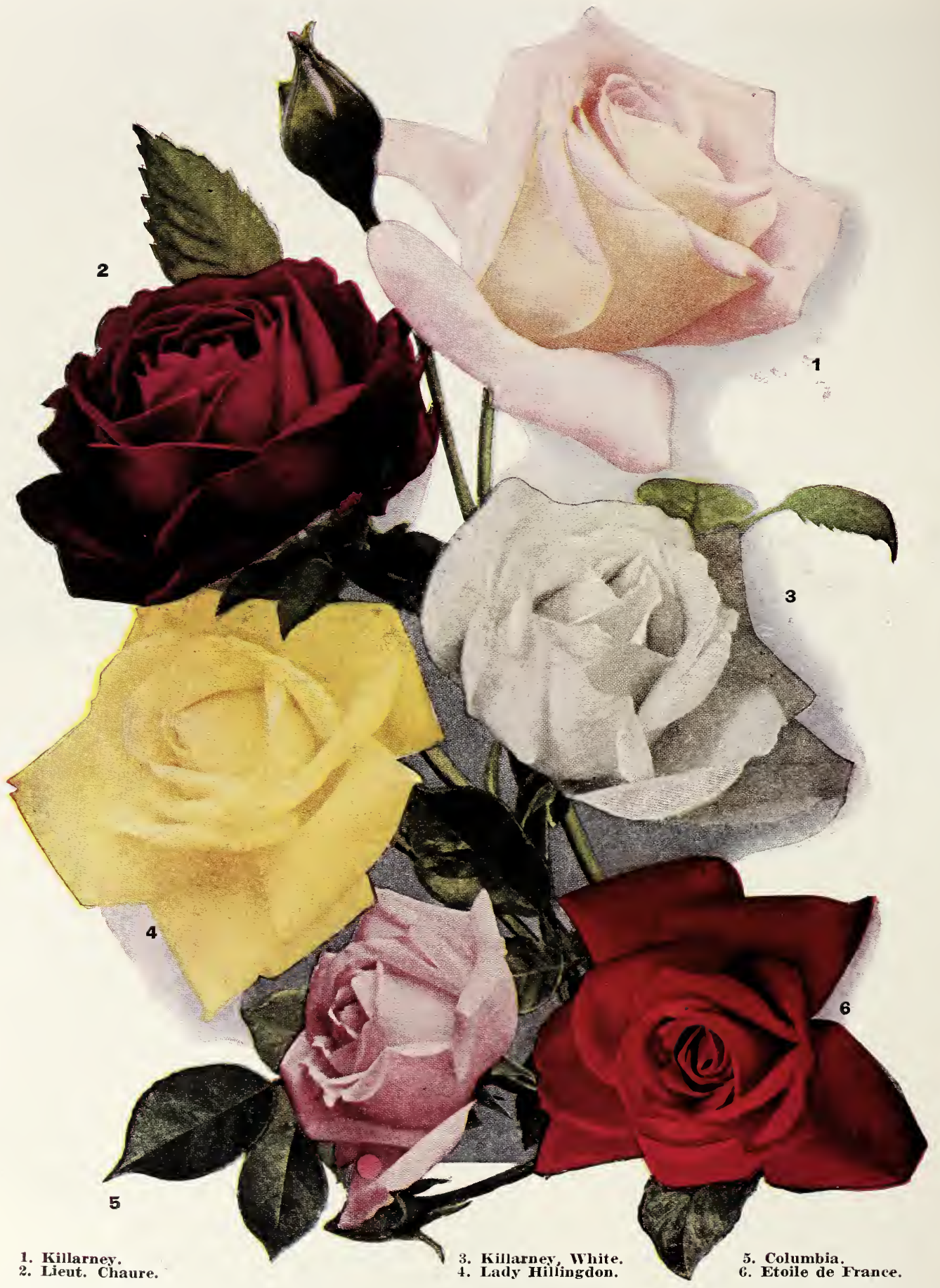

\section{A Group of Hybrid Tea or Monthly Blooming Roses}

Bloom From June Until Frost

One each of the above six Roses for only $\$ 11.00$

Offered in the XXX Size and for Spring Delivery Only 


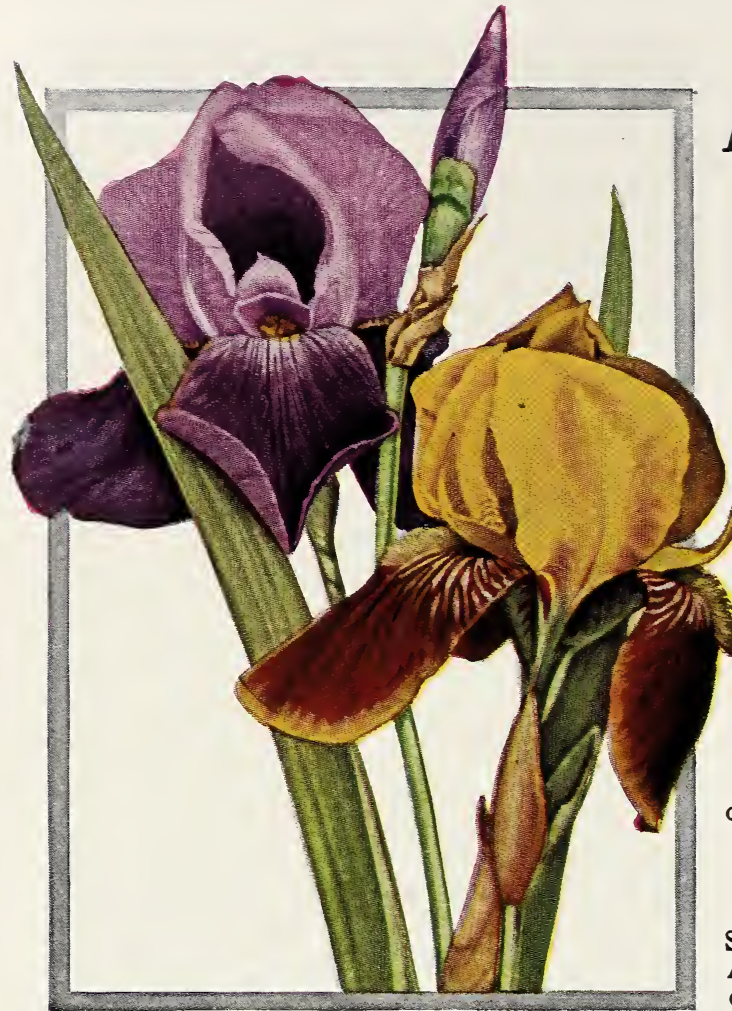

German Iris. 50c each; $\$ 5.00$ per dozen.

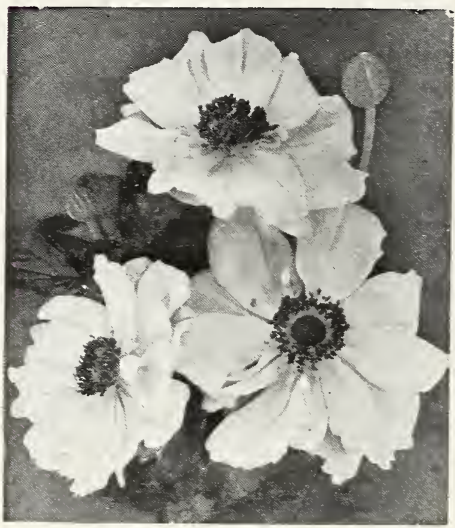

Anemone Japonica.

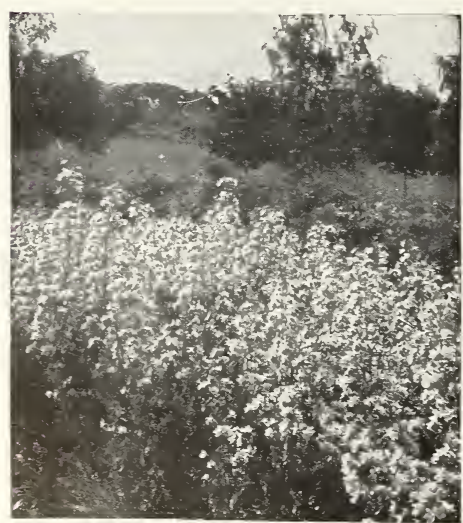

Anchusa Italica.

60 each; $\$ 6.00$ per dozen. every year. white flowers.

\section{Perennial Group No. 1}

12 Hardy Perennials ( 2 of each $\$ 6.25$

$6 \begin{aligned} & \text { Hardy Perennials (1 of each } \\ & \text { shown on this page) }\end{aligned}$ for only... $\$ 3.40$

\section{German Iris}

One of the most dependable plants and very decorative in the garden. Fine in clumps and borders, in fact, most anywhere. Bloom late in May and last into June and are in various shades.

\section{Anchusa Italica (Alkanet)}

Grows to a height of 3 to 5 feet; has rough leaves and stems; branches freely, each branch terminating in a large pyramidal spike of brilliant, blue flowers. Blooms in May and June. Of easy culture.

\section{Hibiscus, Crimson Eye}

Immense flowers of purest white with large centers of velvety crimson. Blooms profusely all Summer.

\section{Digitalis (Foxglove)}

One of the most popular old-fashioned plants. Stalks grow to about three feet. Bloom in July and August. Should be in every planting.

\section{Delphinium}

(Larkspur)

One of our most showy and attractive plants. They are fine among the shrubbery and for sections of borders. Long blooming season. They come in various shades and increase in size and beauty

\section{Anemone Japonica (Windflower)}

A hardy, decorative, free flowering perennial, 2 to 3 feet high, blooming from August until late Fall. One of the best Fall-flowering perennials. We have two varieties: Queen Charlotte, with very large semi-double, rose-pink flowers, and Whirlwind, with large semi-double pure

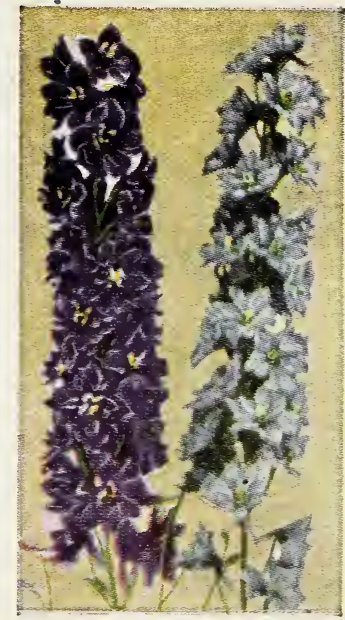

Hardy Delphiniums. 60 c each; $\$ 6.00$ per dozen.

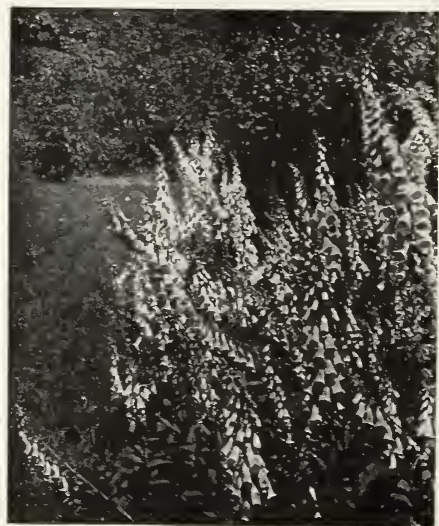

Digitalis-Foxglove. 60 e each : $\$ 6.00$ per dozen.

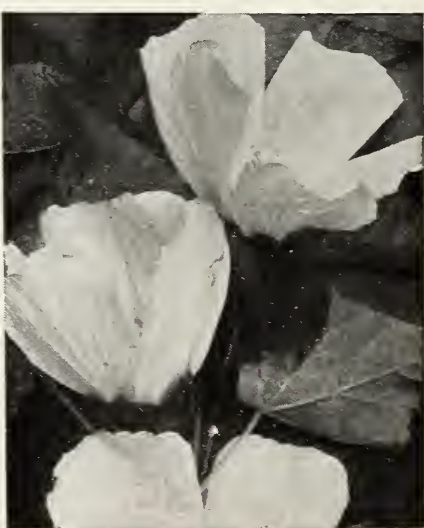

Hibiscus, Crimson Eye. i5e each: $\$ 8.00$ per dozen. 


\section{Perennial Group No. 2}

12 Hardy Perennials (2 of each shown on $\$ \mathbf{6}$ this page) for only...................

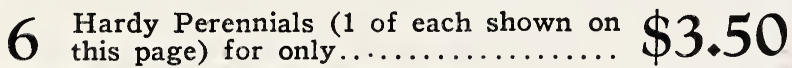

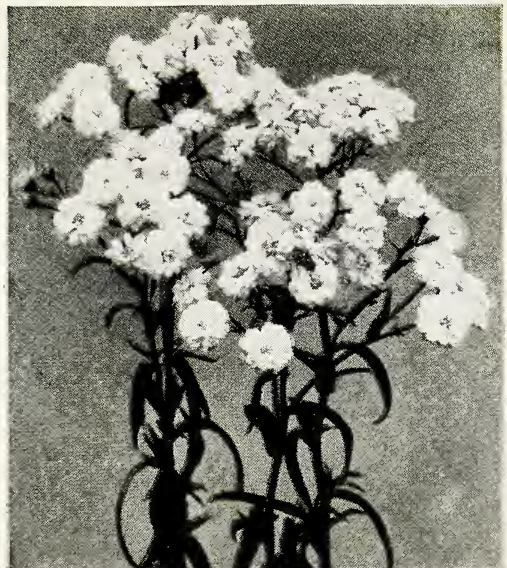

Achillea, "The Pearl." 60c each; $\$ 6.00$ per dozen

\section{Gaillardia}

(Blanket Flower)

A gorgeous perennial. Blossoms in June and will continue all Summer if frequently cut. About two feet high. A hard center of deep maroon is bordered by petals of orange and yellow, ringed by circles of crimson, red and maroon.

\section{German Iris}

See opposite page for description.

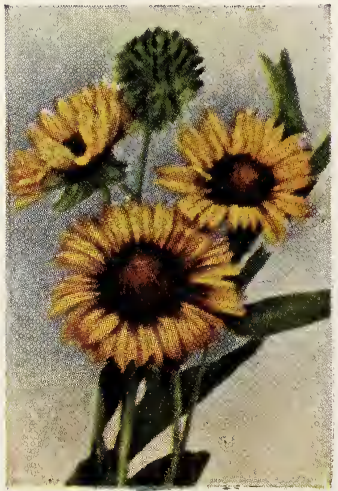

Gaillardia.

60e each; $\$ 6.00$ per dozen.

\section{Achillea, The Pearl}

One of the finest of the white-flowering border plants. Also fine for cutting. About 2 feet high, producing fine, white flowers in profusion during the entire Summer.

\section{Aquilegia}

(Columbine)

Blooms from June till August. Height 2 feet. Flowers are red and yellow, held gracefully on long stems. A strong grower and free bloomer.

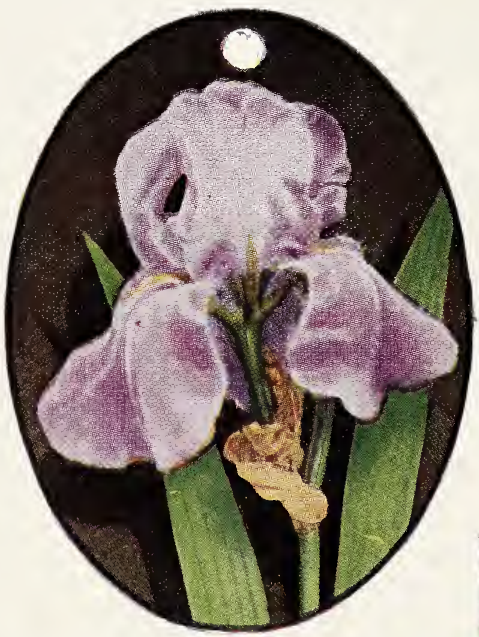

Sweet William

One of grandmother's favorites, and still going strong. About 18 inches high, very hardy. Produces large, flat clusters of flowers of various colors.

\section{Coreopsis}

One of the most satisfactory hardy plants for steady bloom from June on. Flowers of rich, golden yellow and of good size. A strong grower.

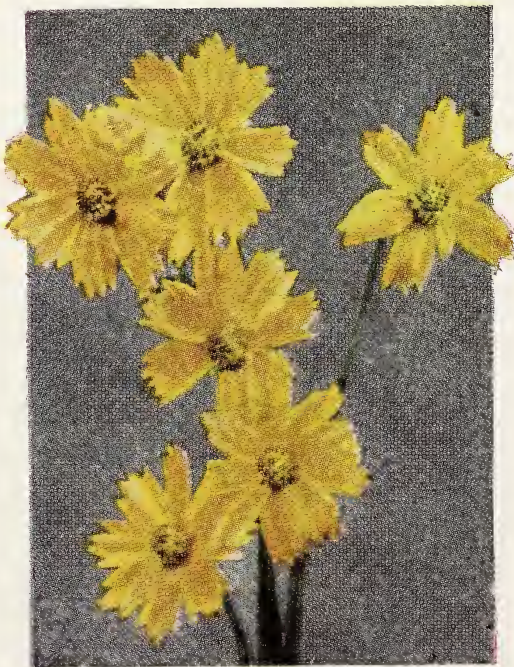

Coreopsis.

60 e each; $\$ 6.00$ per dozen. 


\section{Yucca}

A hardy, evergreen plant. Blossoms on a tall stalk, which terminates in branching spikes of beautiful, creamy white, bell-shaped flowers. Midsummer.

\section{Helianthus}

(Hardy Sunflower)

Flowers are large, from light to deep yellow. Fine for large borders. Blooms in September and October, when flowers are scarce, and is therefore prized for cutting.

\section{Shasta Daisies}

A fine plant for any hardy garden. Blossoms white, and when at their best are sometimes three and four inches across, and are very desirable for cutting.

\section{Hollyhocks}

Fills a place all its own. No other perennial grown is so decorative, so majestic and so stately. It is indispensable in formal plantings, is useful in backgrounds for lower plants, in clumps in large borders, at entrances, in beds in large grounds, on hillsides, in fact almost everywhere. Grows 6 to 8 feet tall, and is in various colors. Should be in every planting for its decorative artistic effect.

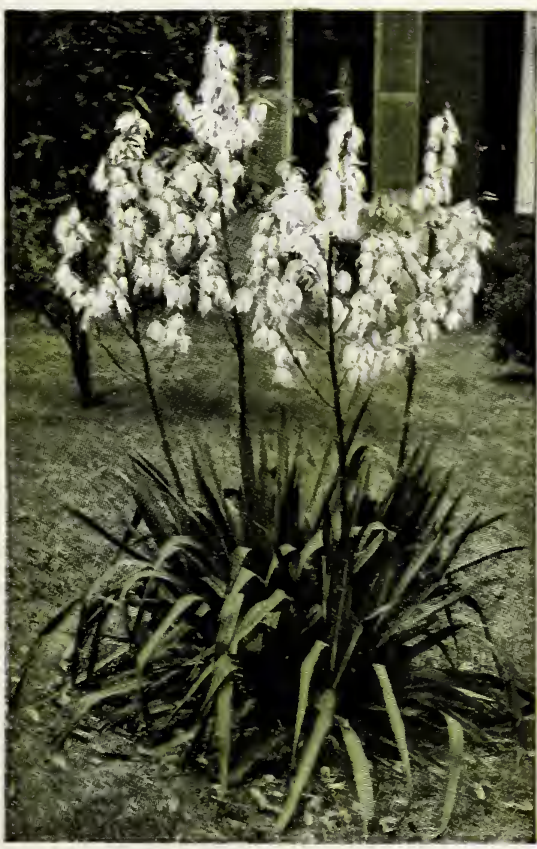

Yucea.

$75 \mathrm{c}$ each; $\$ 8.00$ per dozen.

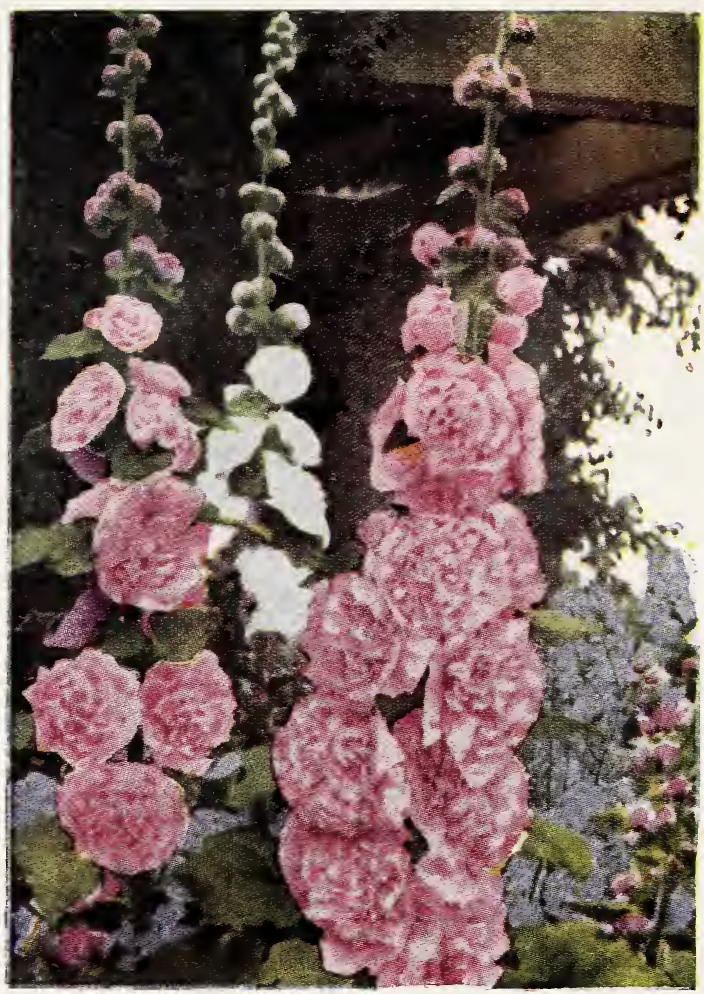

Double Flowering Hollyhocks. $60 \mathrm{c}$ each; $\$ 6.00$ per dozen.

\section{Our Special Hollyhock Group}
1 Red
1 White
1 Pink
1 Yellow

\section{The four for $\$ 2.15$}

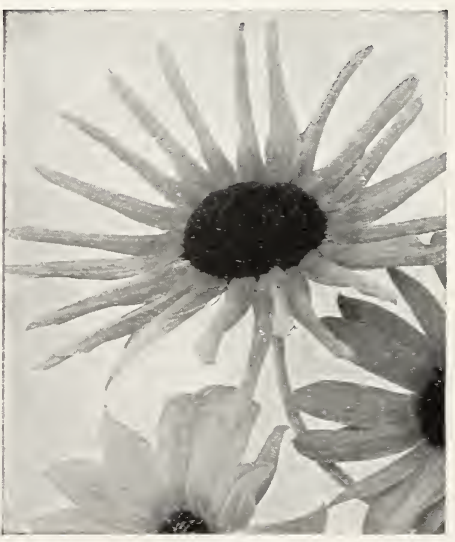

Helianthus.

60c each: $\$ 6.00$ per dozen.

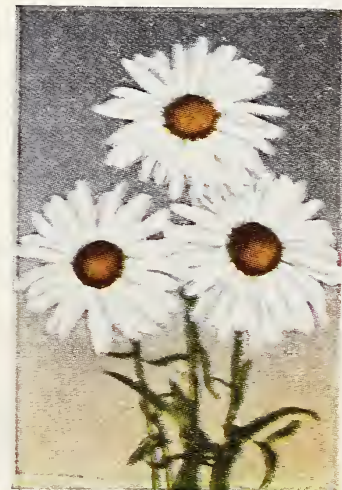

Shasta Daisy. $60 \mathrm{c}$ each. $\$ 6.00$ per dozen. 


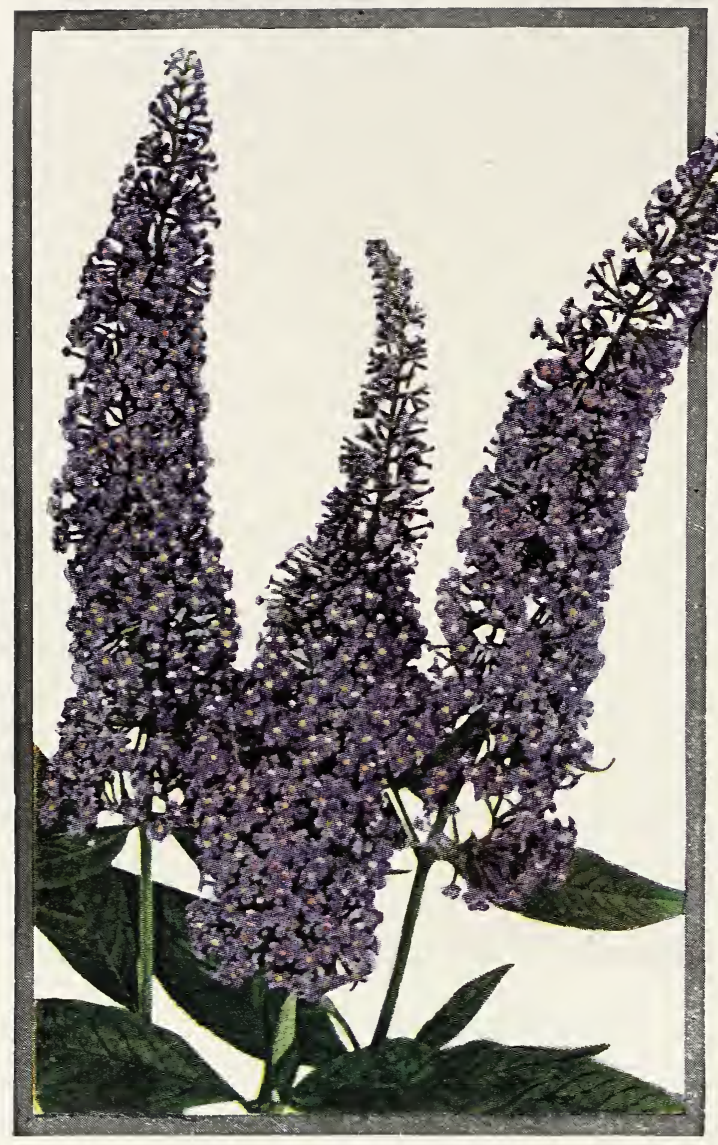

Butterfy Bush.
$\$ 1.00$ each; $\$ 11,00$ per dozen.

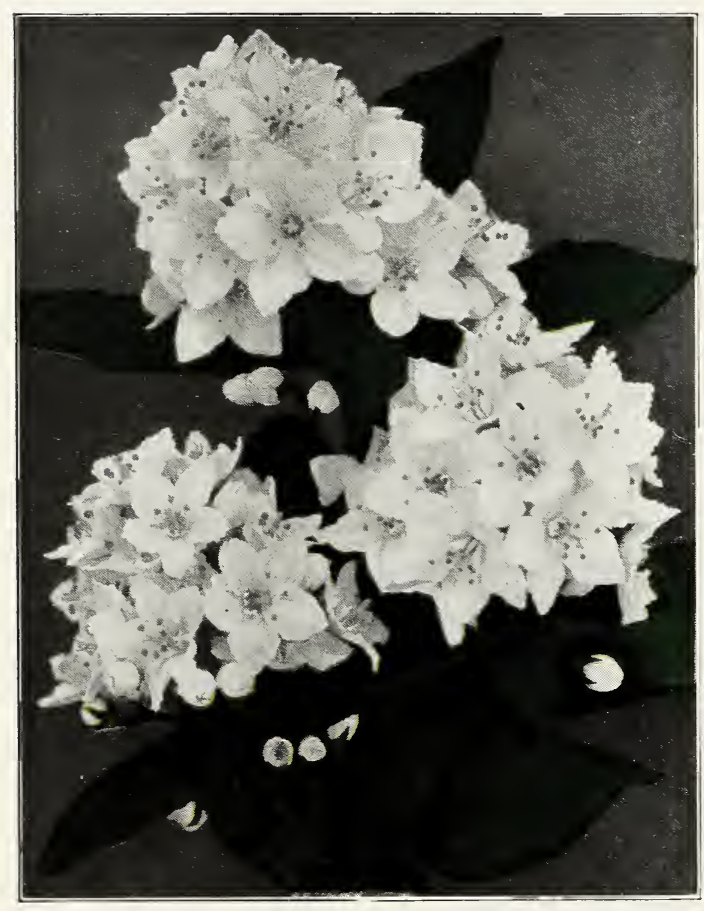

Deutzia Crenata.
$\$ 1.25$ each; $\$ 14.00$ per dozen.

\section{Special Shrub}

One each of these six beau. tiful shrubs shown on this and opposite page for only $\$ 6.50$

\section{Butterfly Bush or Summer Lilac}

3 to 5 feet. Blooms continually from July until frost, bearing long, slender, arching spikes of light blue, lilac-like flowers.

\section{Calycanthus}

Has large glossy leaves with straight, strong, reddish brown branches. Chocolate colored blossoms. Wood, flower and leaves give off a sweet, spicy, strawberry-like fragrance.

\section{Deutzia Crenata}

A beautiful white, single-flowered variety. Bears a mass of scented flowers early in June. Blossoms last a long time. Fine for cutting.

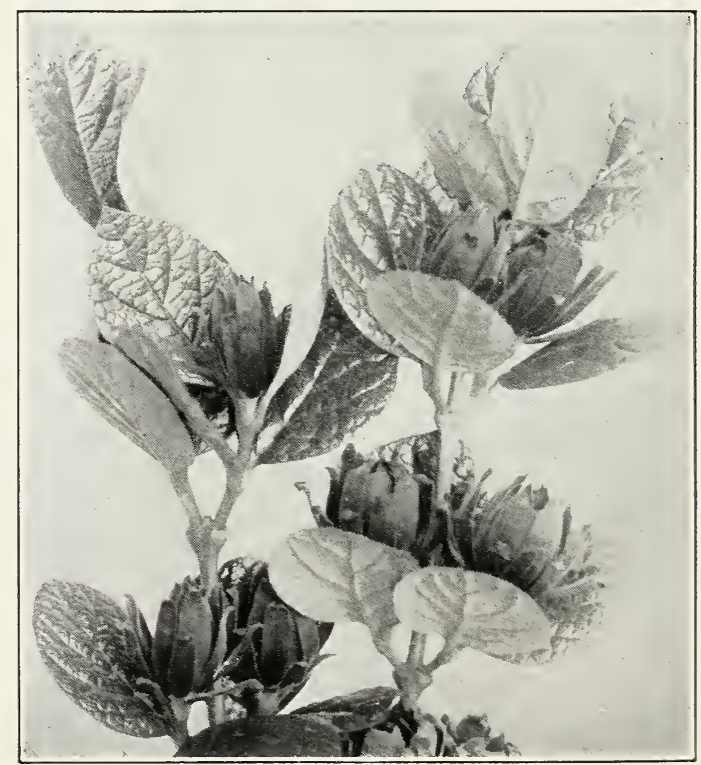

Calycanthus.

$\$ 2.50$ each: $\$ 29.00$ per dozen. 


\section{Group No. 1}

These shrubs are usually less than five feet tall when fully grown.

\section{Coralberry}

(Symphoricarpos vulgaris-RedFruited Snowberry)

Fine foliage, slender, graceful bending branches, and dainty, pink blossoms in June and July are followed by thick clusters of small red berries which last well into the Winter.

\section{Spirea Anthony Waterer}

Crimson flowers in July. The shrub is small, compact; foliage green and dense. Fine in front of taller shrubbery. Spirea Van Houttei with Anthony Waterer in front makes a combination which cannot be beaten.

\section{Snowberry}

(Symphoricarpos racemosus-White-Fruited Snowberry)

Dainty small pink flowers in June and July, which in August form into pure white, waxy berries. An excellent shrub for grouping and massing. Very hardy, does well in shade.

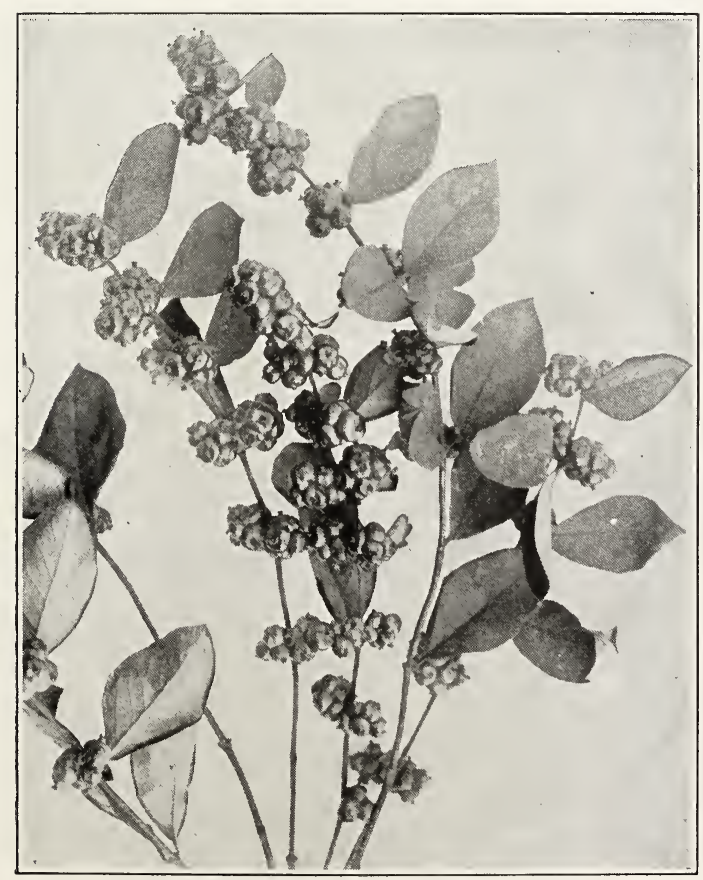

Red-Fruited Snowberry or Coralberry. $\$ 1.00$ each; $\$ 11.00$ per dozen.

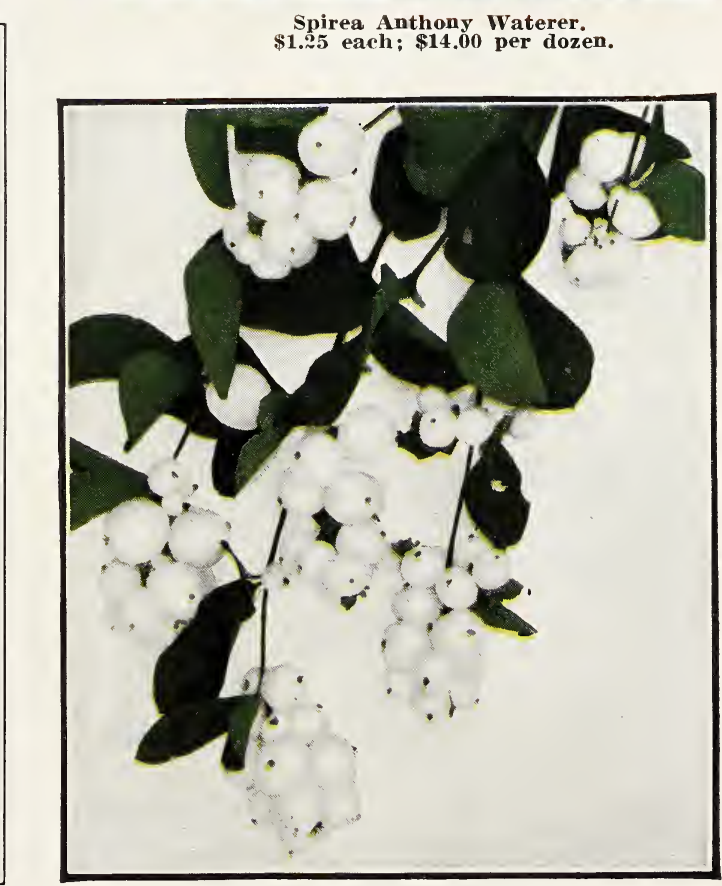

White-Fruited Snowberry. $\$ 1.25$ each; $\$ 14.00$ per dozen. 


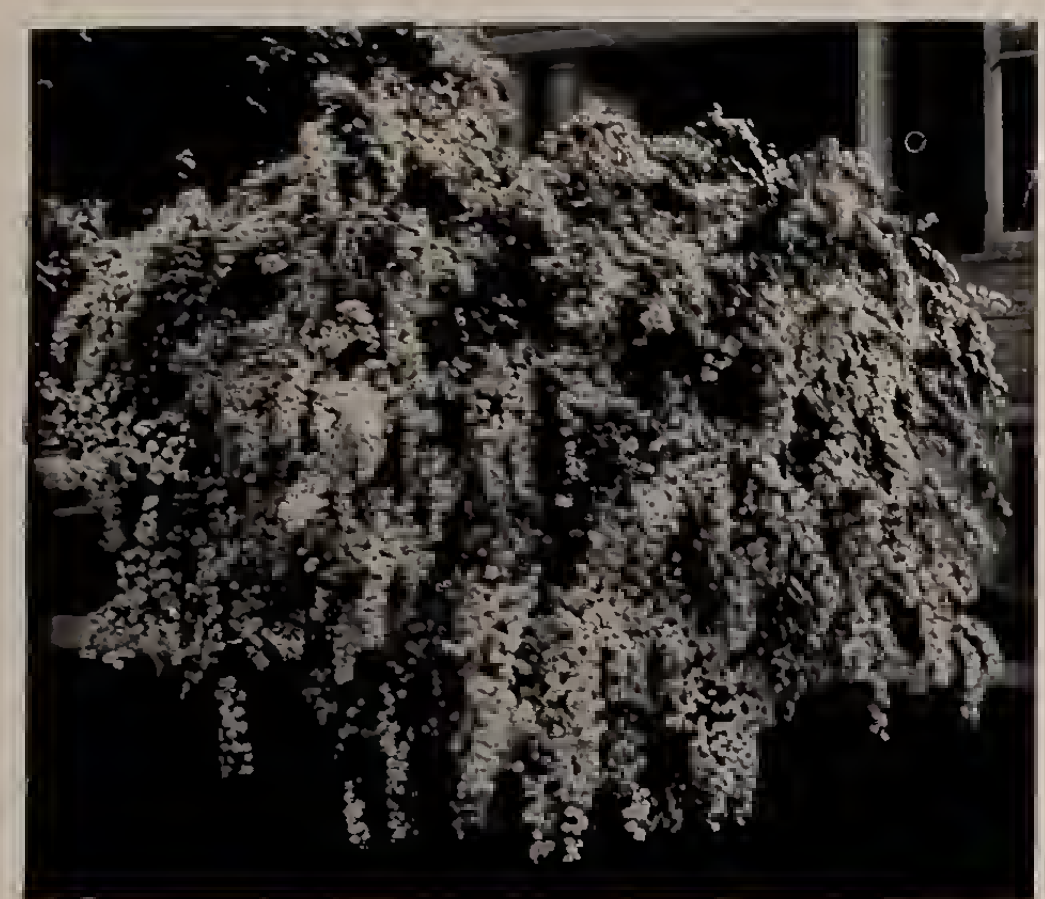

Spirea Van Houttej. \$1.00 each: \$11.00 per dozen.

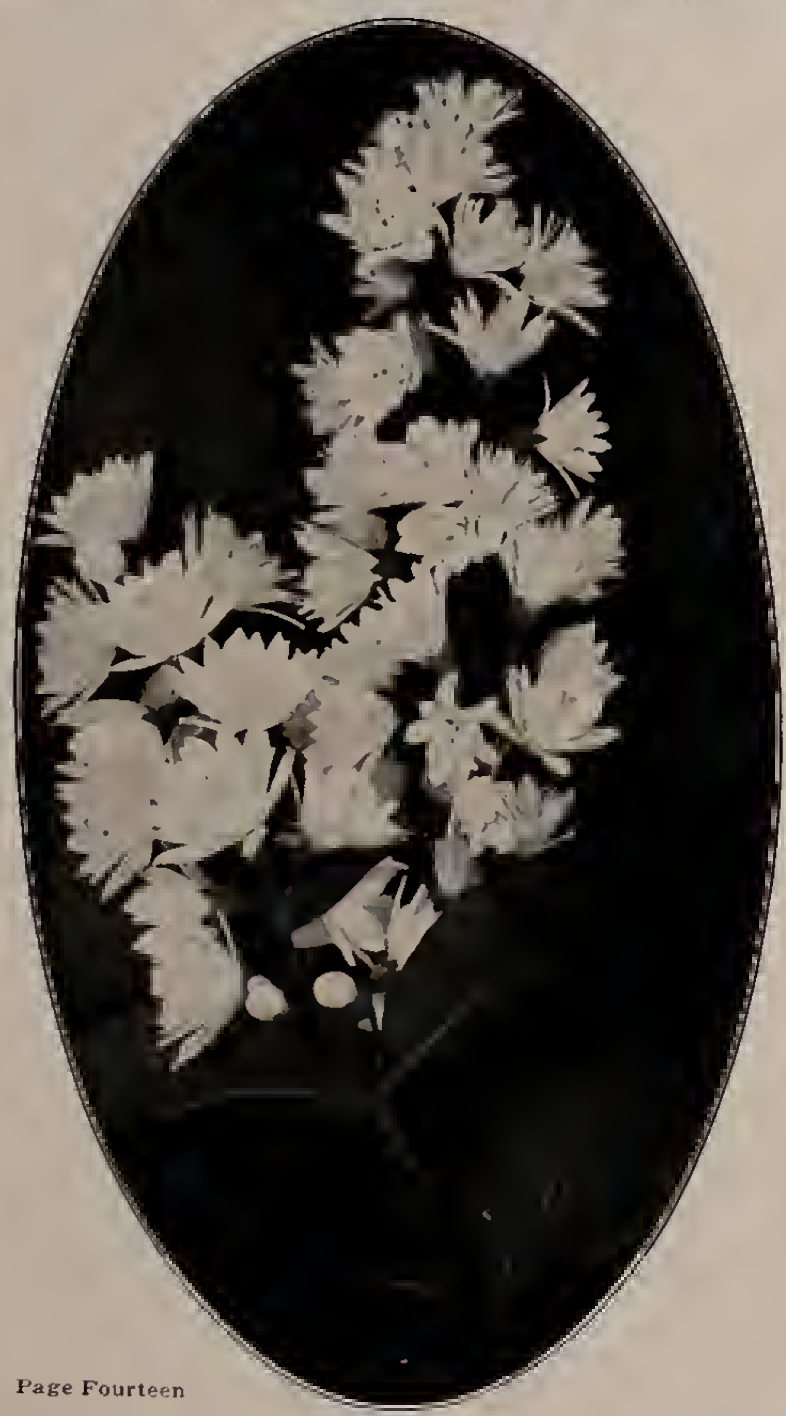

Deutzin, Pride of Koehenter.
$\$ 1.25$ earll1: $\$ 14.00$ per dowen.
Special Shrub Group No.2

Shrubs about 6 to 8 feet in height when fully grown One each of these six attractive Shrubs for only $\$ 7.00$

\section{Spirea Van Houttei \\ Weigela Rosea}

The favorite Spirea. So well known it requires no description.

SPECIAL 6 Spirea

Van Houttei, $\$ 5.00$

Deutzia

Pride of Rochester Showy clusters of white flowers
tinged with pink in May and June.

Syringa Coronarius or Mock Orange

This is the familiar "Mock Orange." Bears very fragrant creamy white flowers in May and June. A fine, hardy shrub.

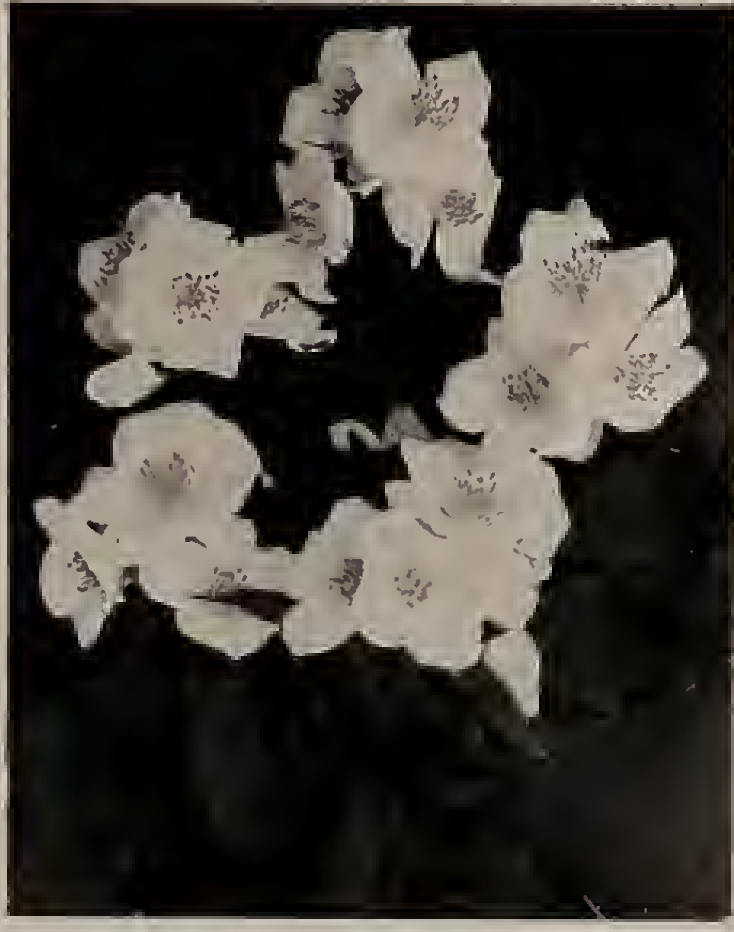

Sy ringa Coronariss-Mock Orange.
$\$ 1,25$ each: $\$ 14,00$ per dozen.
One of the choicest of all shrubs. Highly decorative and very hardy.

Althea

or Rose of Sharon

Blossoms late in season when blooms are scarce. May be had with bloom of either white, pink, red, blue or purple.

\section{Tartarian}

Bush Honeysuckle

Bears a profusion of small, fragrant blossoms in May and June, followed by orange or red berries, which frequently last into early Winter.

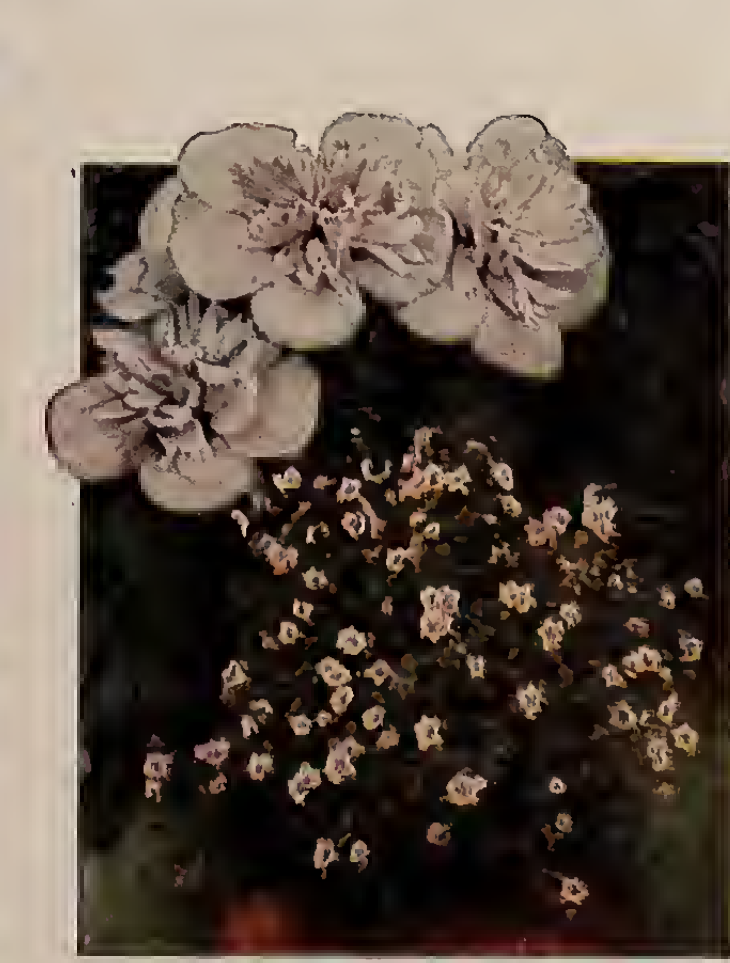

Althea, Rose or Sharon.
$\$ 1.25$
enchic
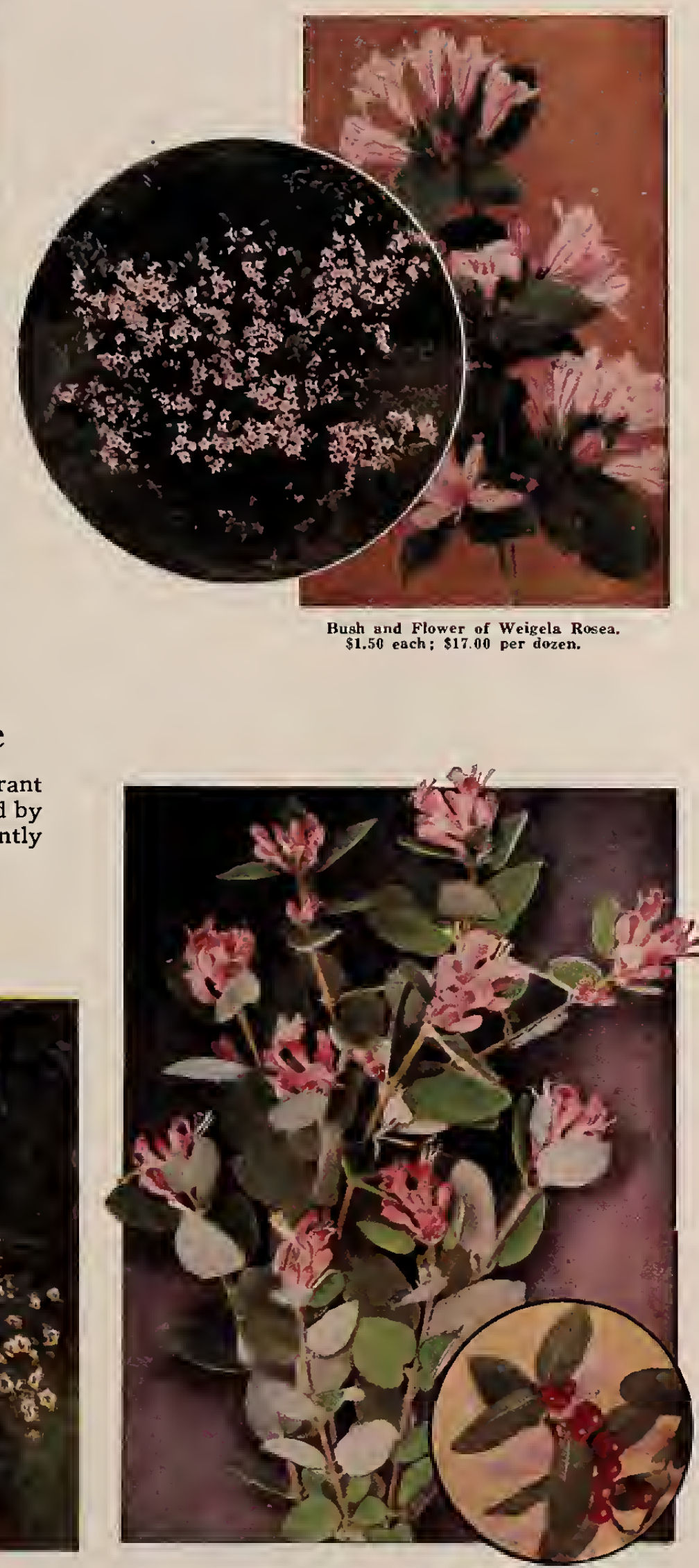

Tartarian Bush Honeysuckle.
$\$ 1.25$ each: \$14.06 per dozen. 


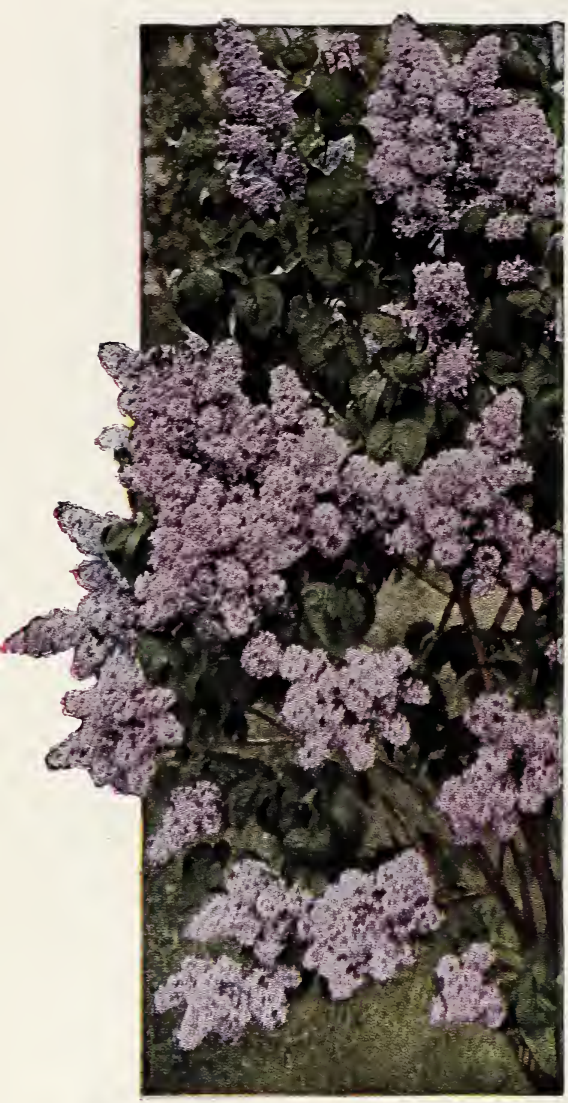

Purple Lilac.
$\$ 2.00$ each; $\$ 23.00$ per dozen.

\section{Special Shrub}

Shrubs usually over 8 feet in height when fully grown and are especially adapted where a high screen is'desired.

\section{Purple Lilac}

Purple flowers are scarce, hence the advisability of planting this old favorite.

\section{Spirea Aurea}

Very vigorous. Large, white blossoms in June. Fine for screens.

\section{Syringa Grandiflora}

A strikingly showy shrub. Has white blossoms in June, followed by large red seed pods lasting throughout July.

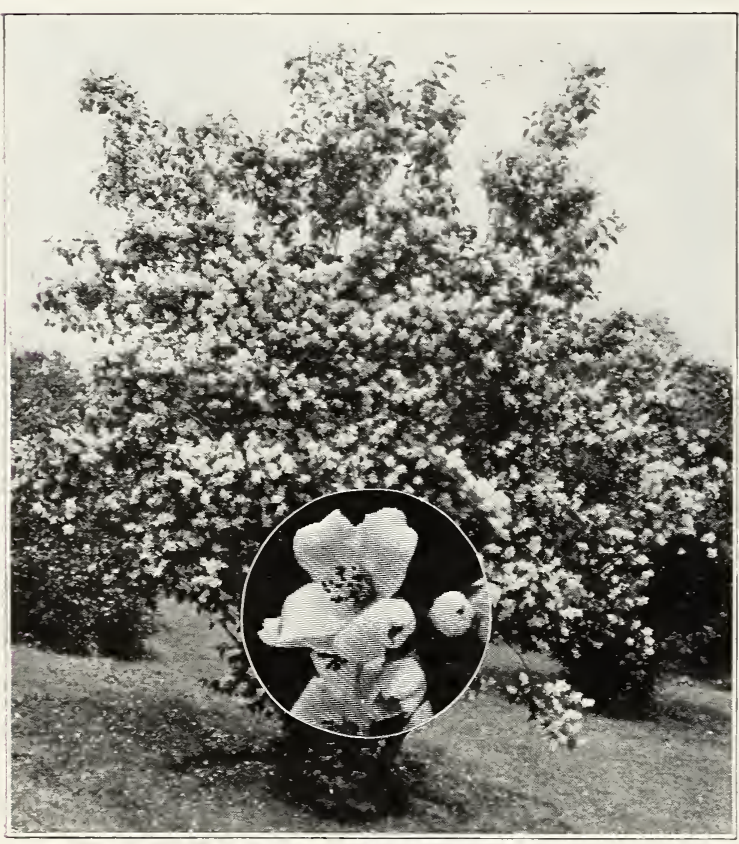

Syringa Grandiflora.

$\$ 1.25$ each; $\$ 14.00$ per dozen.

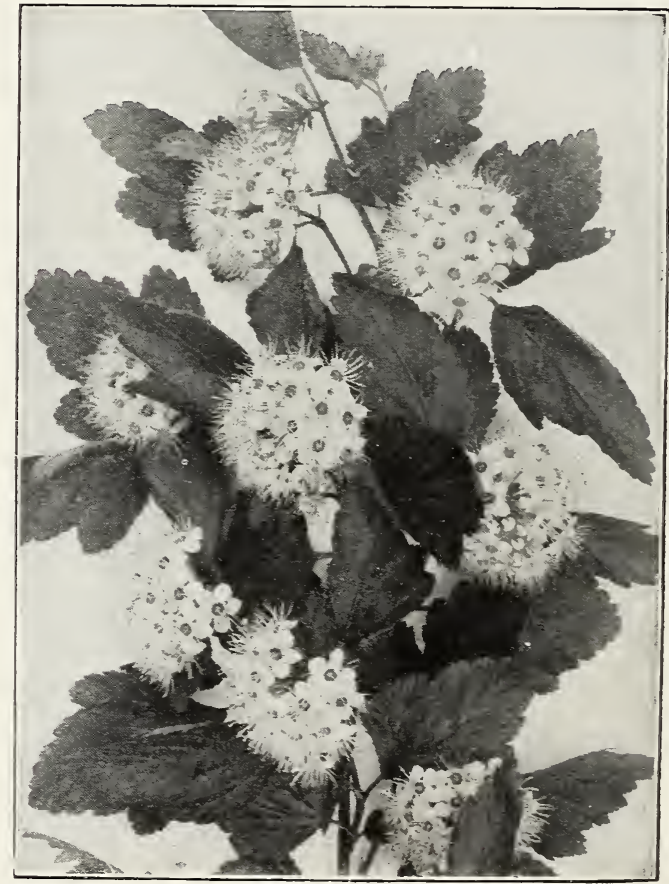

Spirea Aurea.

$\$ 1.25$ each; $\$ 14.00$ per dozen. 


\section{Group No. 3}

One each of this group of five shrubs shown on this and opposite page for only

$\$ 6.25$

\section{Tamarix}

A strangely beautiful shrub. Blossoms in April, flowering profusely in delicate feathery sprays of light pink and white blossoms. Handsome even when out of flower on account of its fine feathery foliage.

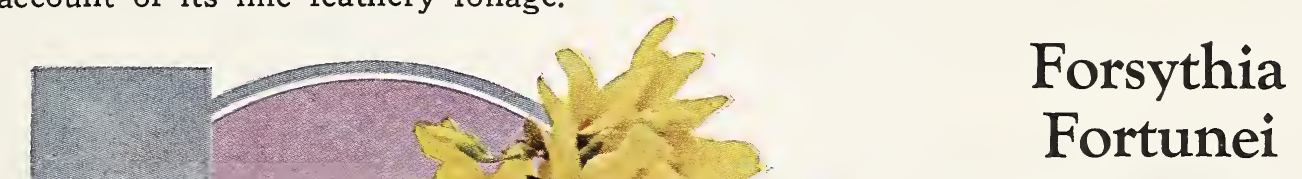

Small, yellow blossoms before its leaves are out. Hardy and profuse bloomer. One of the first shrubs to bloom in the Spring.

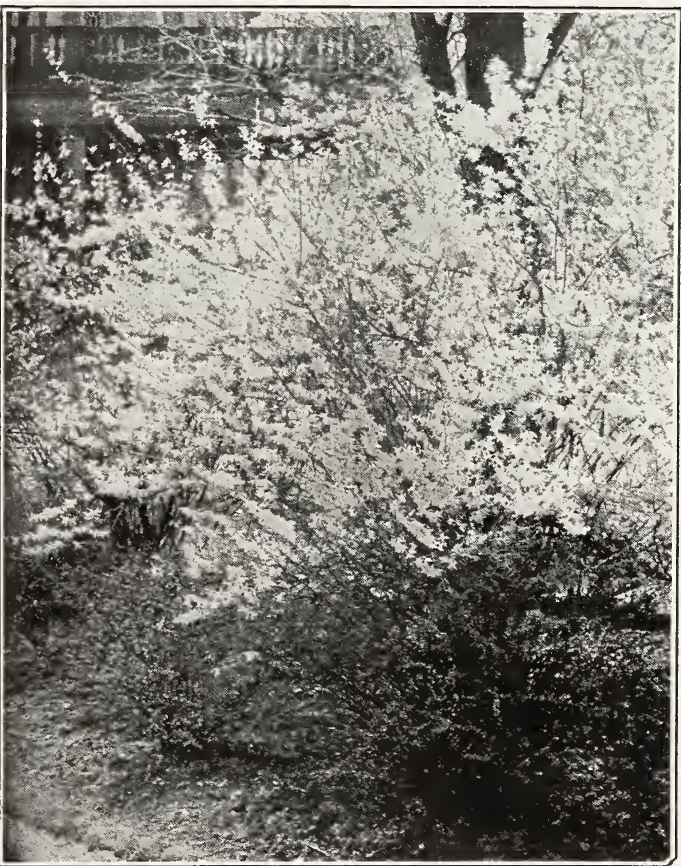

Forsythia Fortunei Bush. 


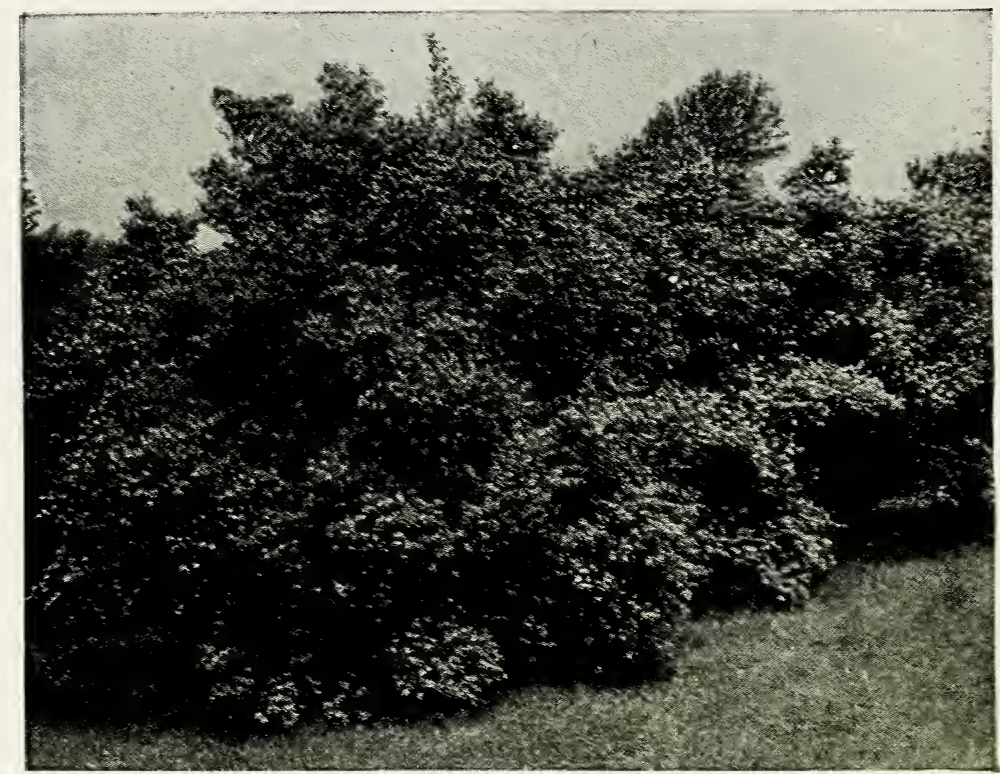

Lonicera Morrowi-Morrow's Honeysuckle.

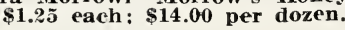

\section{Spirea Billiardi}

Dense spikes of exquisite pink flowers in July and August. Has second but less profuse blooming period in Fall. One of the most popular Spireas.

\section{Honeysuckle Morrow's}

Has pure white flowers which change to yellow tones in May and June. These are followed by a multitude of bright red berries which remain from August until Winter. Attracts birds.

\section{Forsythia Viridissima}

Compact branches with yellow flowers preceding its leaves. Desirable for massing.

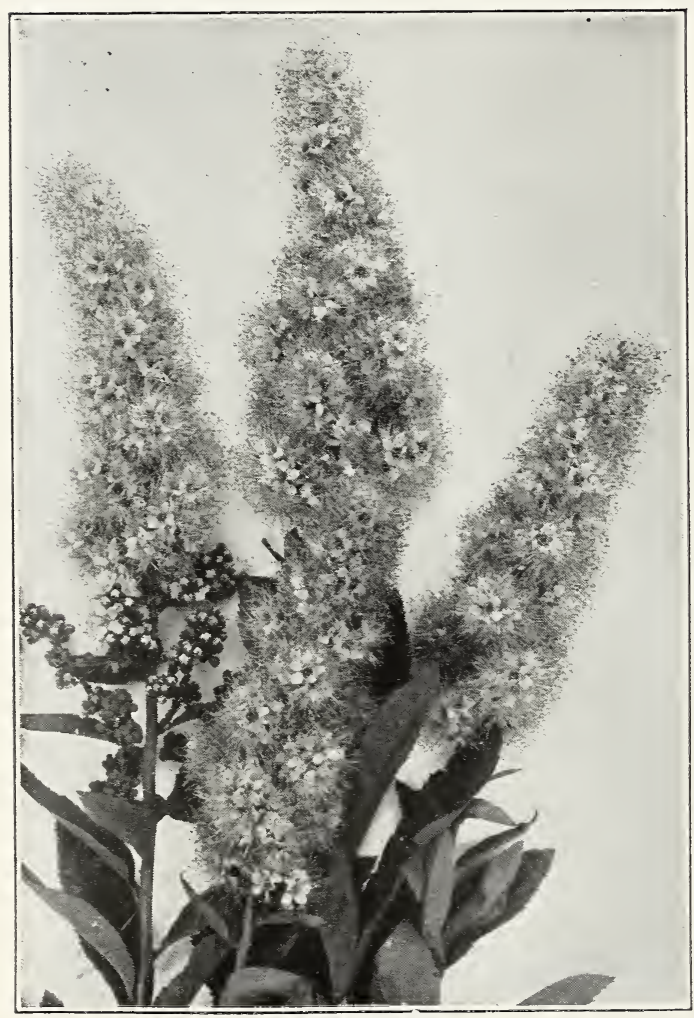

Spirea Billiardi.

$\$ 1.25$ each; $\$ 14.00$ per dozen.

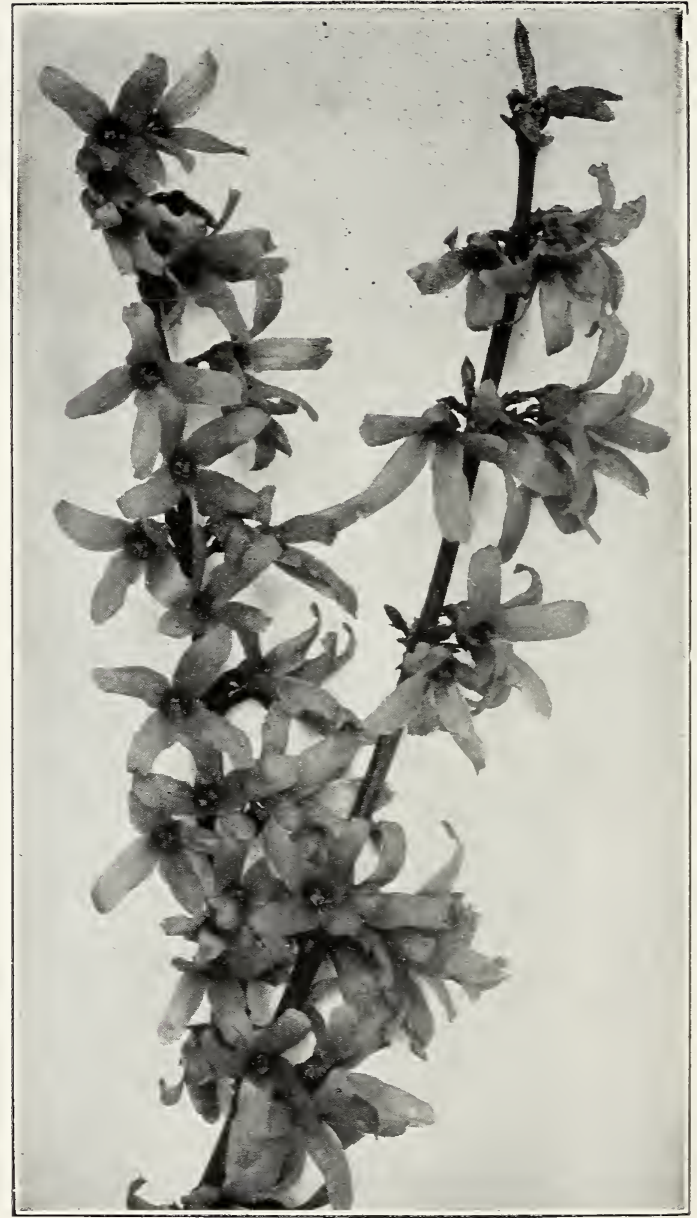

Forssthia Viridissima.

$\$ 1.00$ each; $\$ 11.00$ per dozen. 


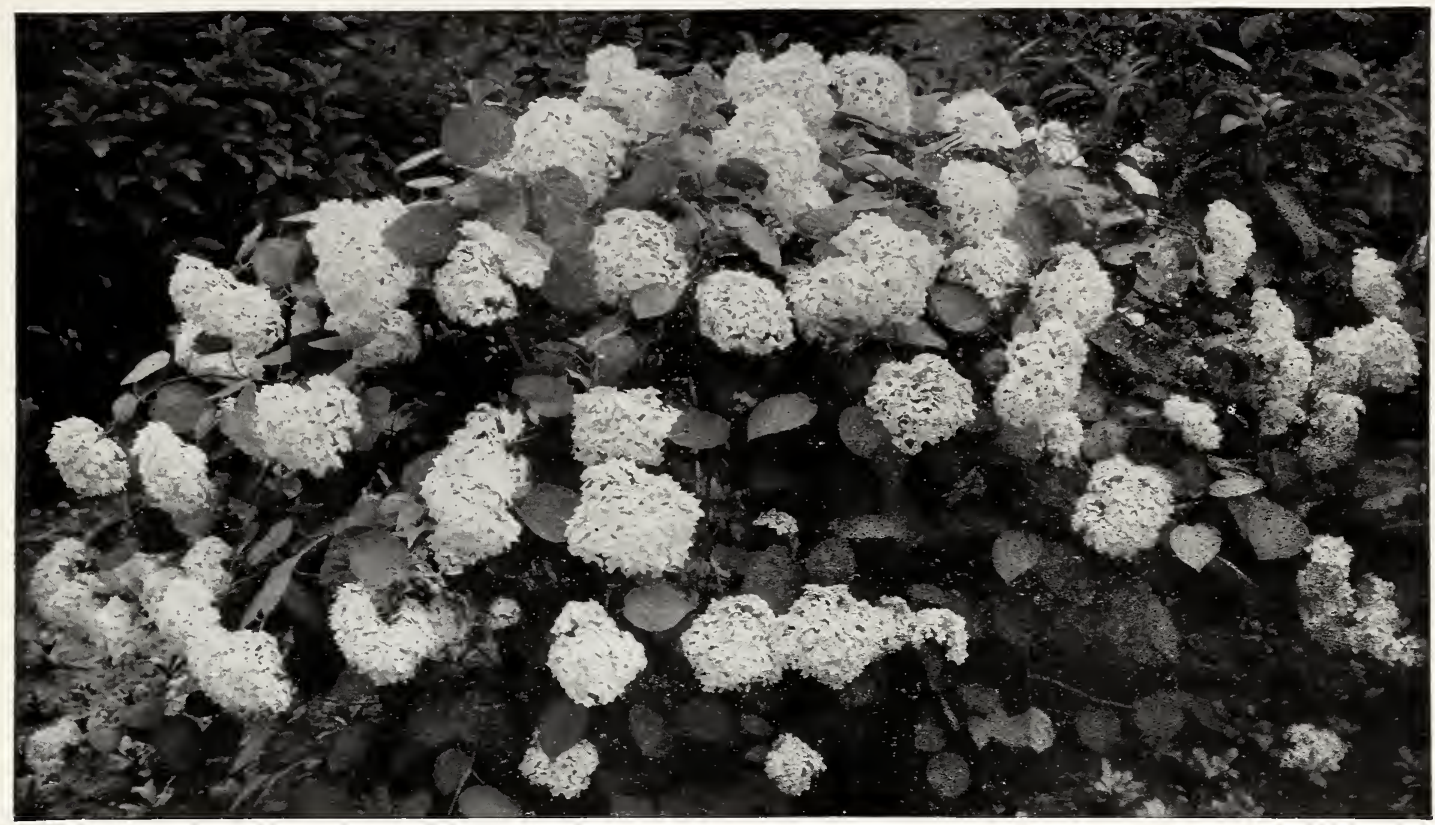

Hydrangea Arborescens-Hills of Snow. $\$ 1.50$ each; $\$ 17.00$ per dozen.

\section{Hydrangea Arborescens (Hills of Snow)}

Becomes a good sized shrub to which the name Hills of Snow may well be applied-a profusion of large, snow-white flowers turning green instead of bronze as do other $\mathrm{Hy}$ drangeas. Easily grown in ordinary garden soil and thrives in partial shade, but does best in full sun. It blooms from June till August, when the Paniculata begins. Strong, fieldgrown plants.

\section{Hydrangea Paniculata Grandiflora}

The most popular of all the Hydrangeas. Has immense, cone-shaped, white blossoms which turn to pink. This shrub is the most showy of all in the Fall and therefore very valuable. Is fine as a single specimen plant or in beds or borders. Perfectly hardy in smoky or dusty locations, and also does well in the shady corner.

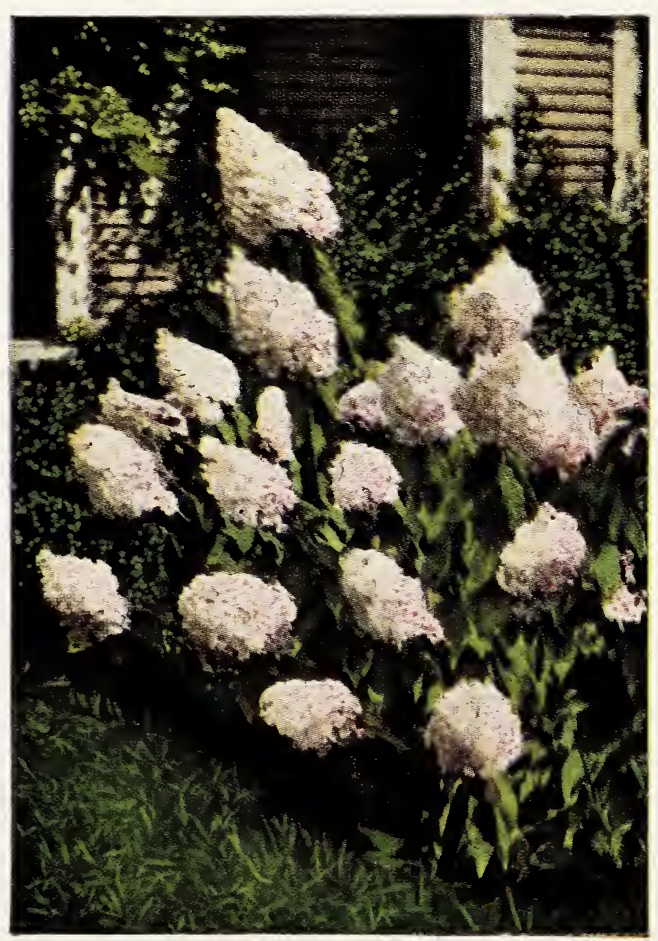

Hydrangea Paniculata Grandiflora Bush. \$1. ̃o each: $\$ 1$ i 00 per dozen. 


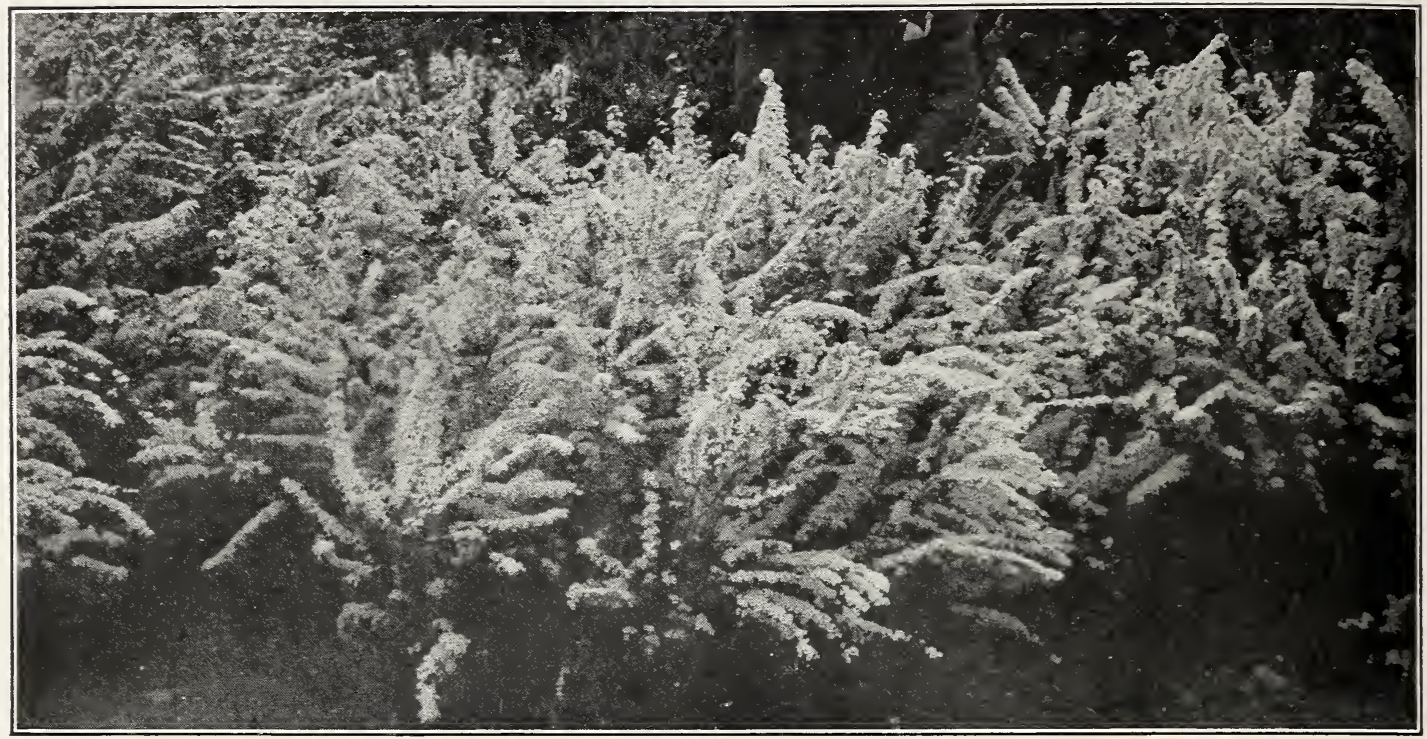

Spirea Garland. $\$ 1.50$ each; $\$ 17.00$ per doz.

\section{Spirea Garland}

The New Spirea. Its white blossoms give a beautiful mass effect, fully equal to that of the Van Houttei. Wonderful for planting in front of Spirea Van Houttei as it blooms about three weeks earlier, thus giving about six weeks of Spirea bloom. The two grow well together. The bush itself is very attractive, taking on a fine Fall coloring and holding its foliage well throughout the Winter.

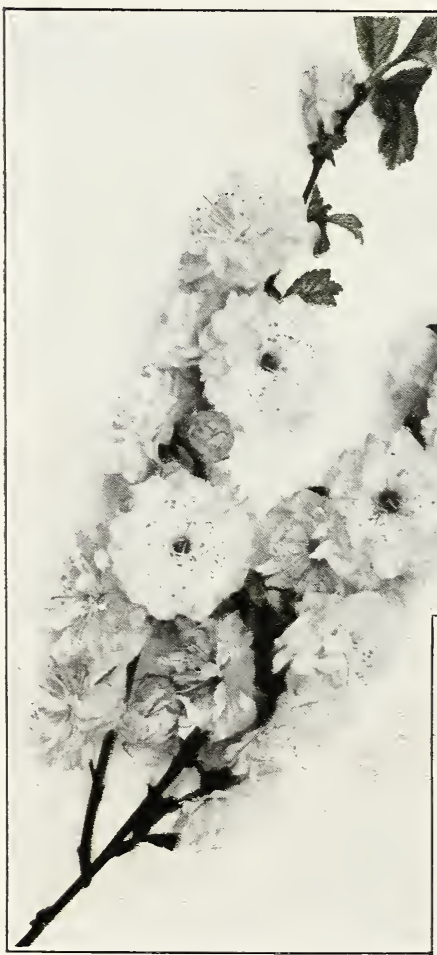

Prunus Triloba or 1 Iouble-Flowering Plum. \$3.00 each.

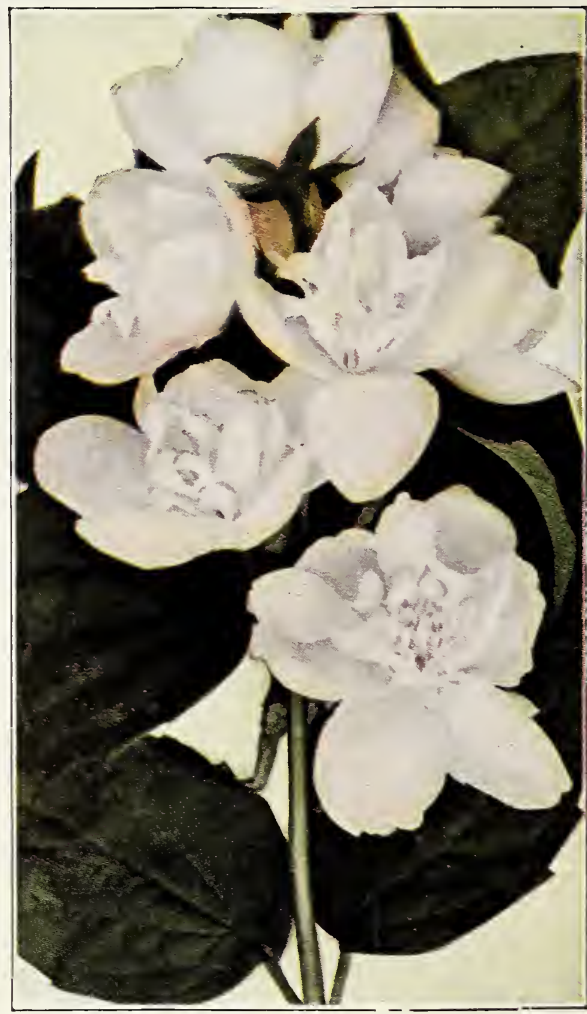

Syringa Virginalis or Double-Flowering Mock Orange. \$2.00 each; $\$ 23.00$ per dozen.

\section{Syringa Virginalis}

(or Mock Orange)

Une of the most beautiful new varieties. A vigorous, tall grower, with very large, double-crested flowers, with round petals. Pure white, sweetly scented clusters of five to seven blossoms.

\section{Prunus Triloba}

\section{(or Double Flowering Plum)}

Native of China. Flowers double, of a delicate pink, upwards of an inch in diameter, thickly set on the long, slender branches; flowers in May. 


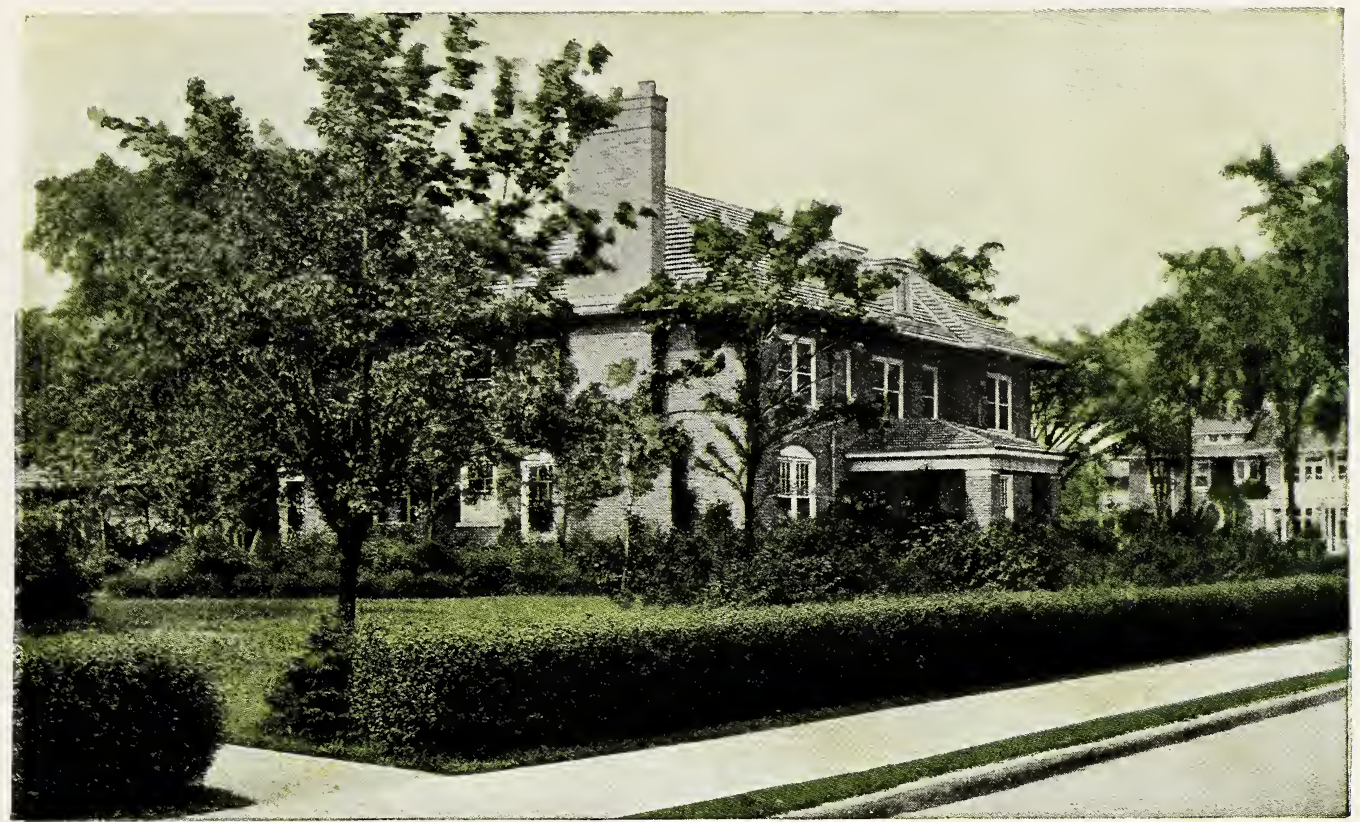

California Privet Hedge.

\section{California Privet}

The most popular Privet for hedges. Untrimmed it will attain a growth of from 6 to Io feet but it is far more attractive when trimmed to a height of about 3 to 4 feet. A beautiful effect is produced when it is planted in two rows, the plants 12 to 18 inches apart and "staggered." Does well in smoke, dust and shady places.

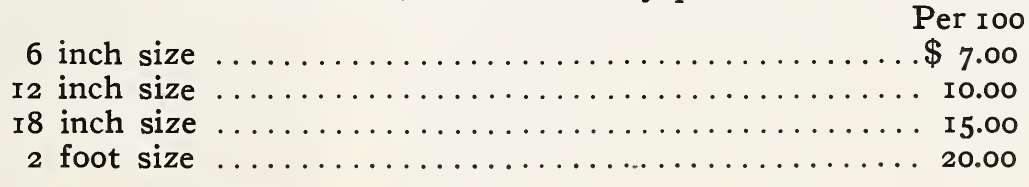

\section{Barberry Thunbergi}

The best of all hedges for low, informal effects. One of the hardiest of all hedges being especially adapted for planting in cold climates. The foliage is very fine, in the Autumn taking on a gorgeous coloring, and the berries, which remain all Winter, are red and very attractive. Barberry Thunbergi is suitable for many other purposes than hedging. As a foundation planting there is nothing better; it is splendid for covering hillsides; for the shrubbery border; for corner clumps; for bordering driveways and for many other

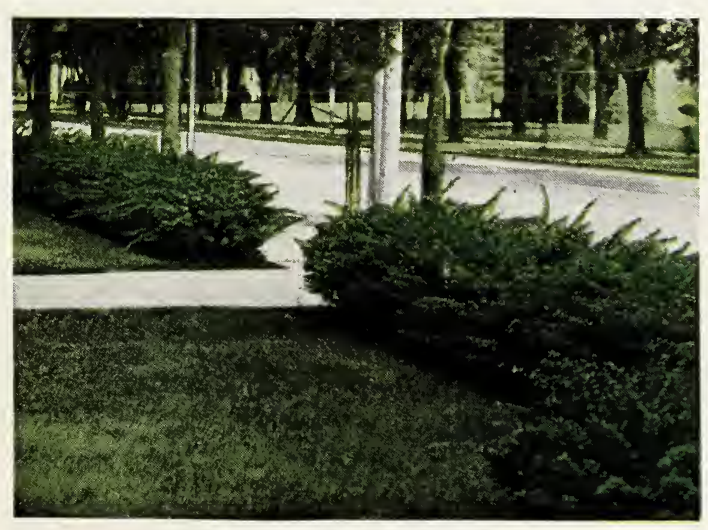

Barberry Thunbergi Hedge. purposes. Many people who have not had success in growing evergreens for foundation planting or on terraces have used Barberry, which, when it attains a good growth, can be trimmed to any desired shape. We have seen plantings of Barberry trimmed to simulate Arbor-Vitae Globosa, Arbor-Vitae Pyramidalis, Retinispora Squarrosa, and in fact in all symmetrical shapes.

Per 100

I2 inch size $\ldots \ldots \ldots \ldots \ldots \ldots \ldots \ldots \ldots \ldots . \ldots \ldots$

I8 inch size ................60.00

2 foot size ............... 85.00

Seedlings, 9 to I2 inch size ....... I 5.00 


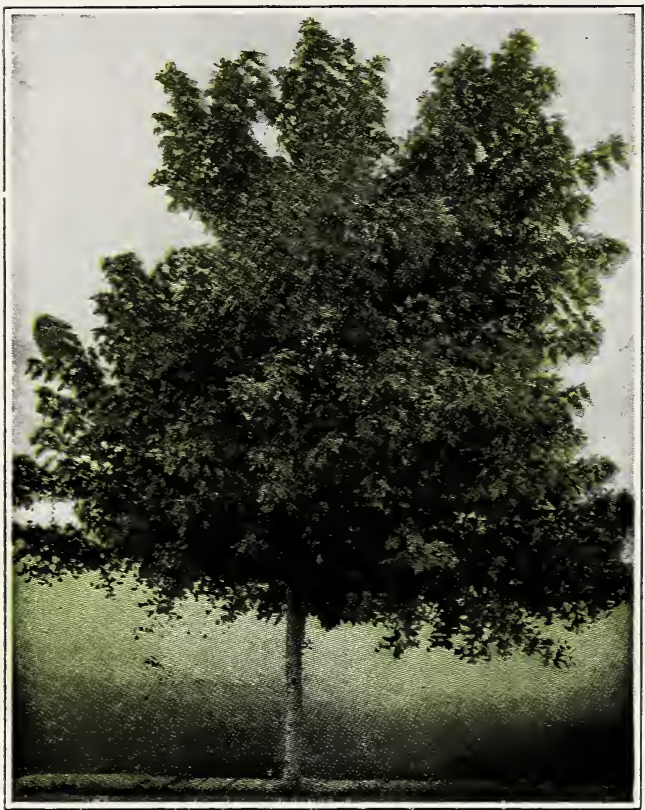

Silver Maple.

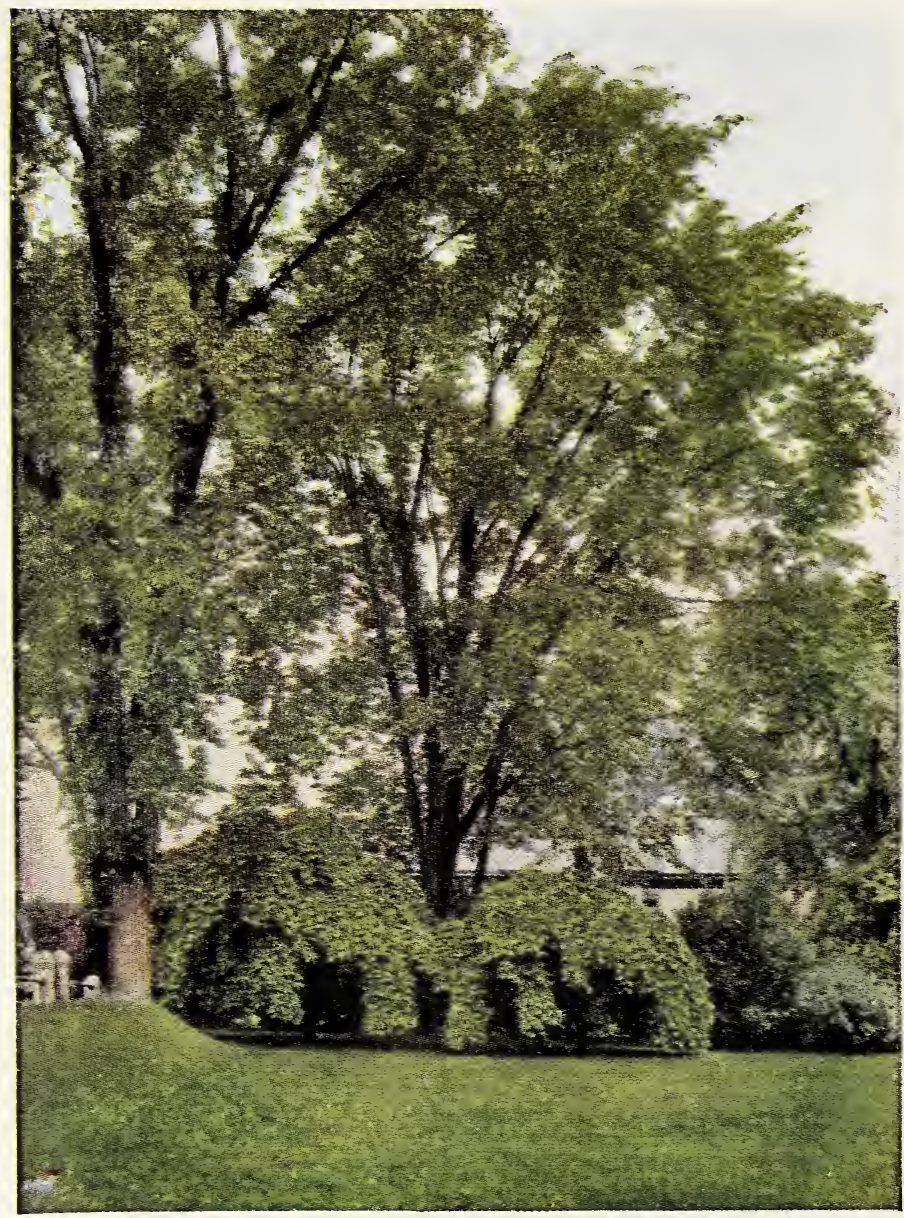

American Elm (Tall Growing).

Camperdown Elm (Weeping).

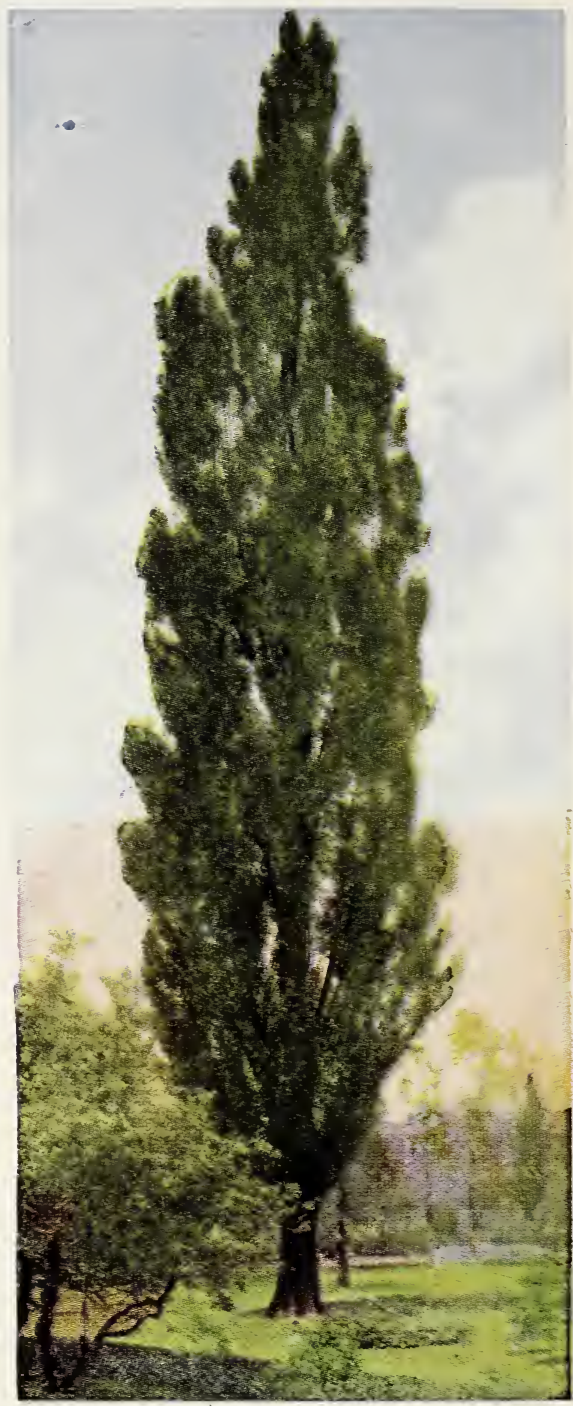

Lombardy Poplar.

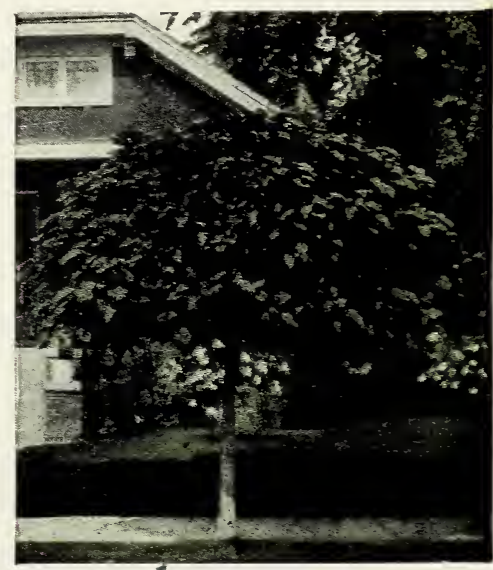

Catalpa Bungei.

(See price list for prices.) 


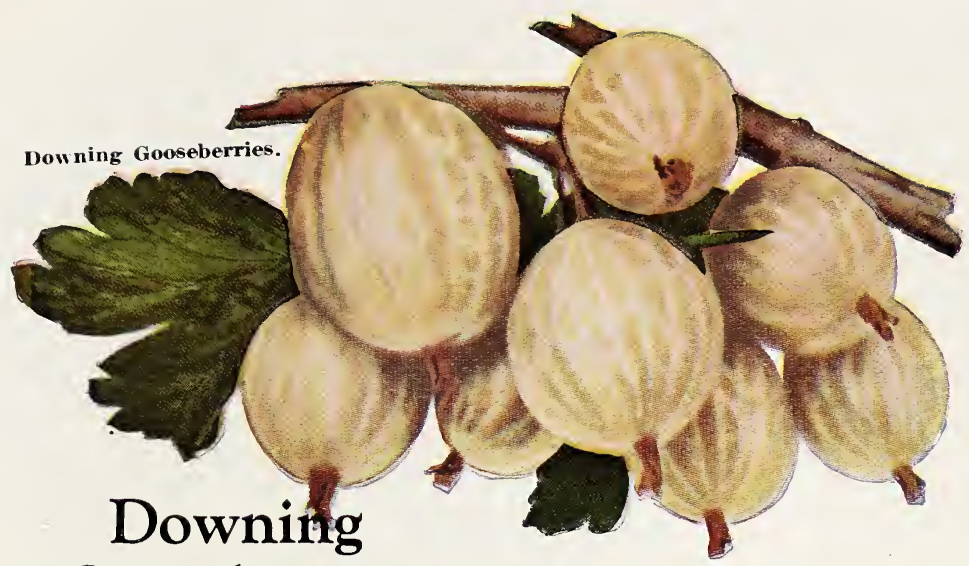

\section{Gooseberries}

Each Doz. Ioo

XXX Size . .\$0.75 \$8.00 \$60.00

\section{Perfection

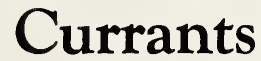

Each Doz. 100 XXX Size. .\$1.00 \$I1.00 \$85.00

$\begin{array}{llll}\mathrm{X} \text { Size. } & .75 \quad 8.00 \quad 60.00\end{array}$

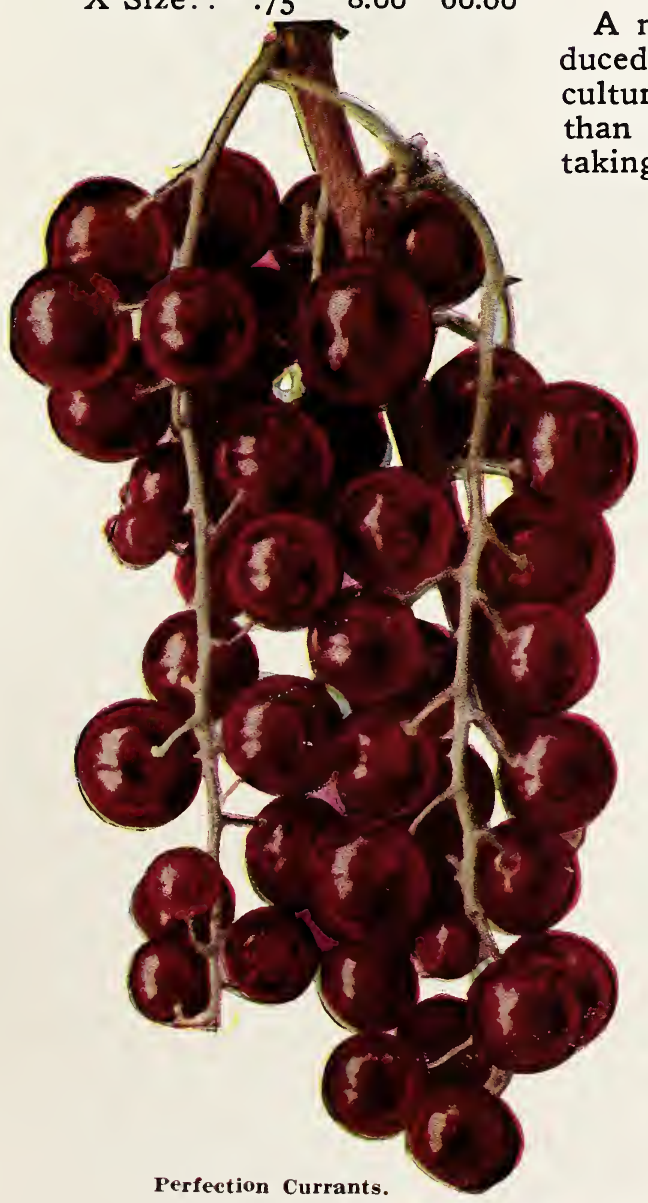

\section{Rhubarb or Wine Plant}

$\$ 5.00$ per doz.; $\$ 30.00$ per Ioo.

\section{Pedigreed Washington Asparagus}

$\$ 2.50$ per $25 ; \$ 8.00$ per $100 ; \$ 40.00$ per 1000.

A new rust-resisting variety produced by the U. S. Dept. of Agriculture. Nearer to being rustproof than any other sort. This is fast taking the place of all other varieties.

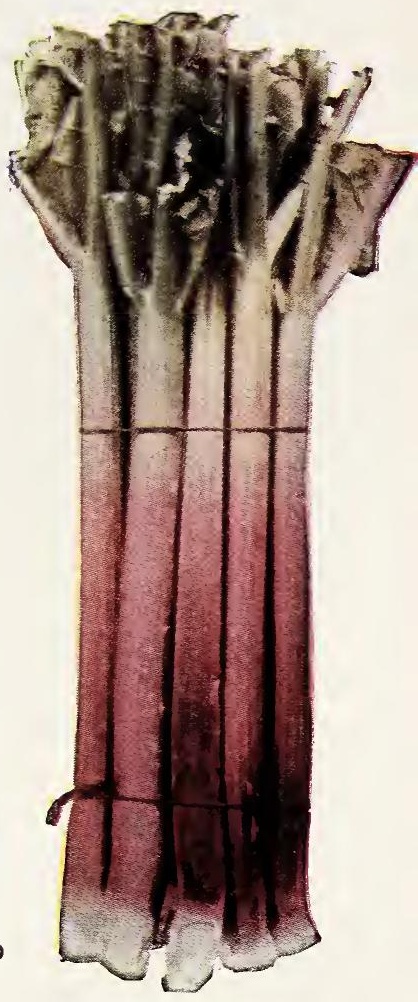

Rhubarb or Wine Plant.

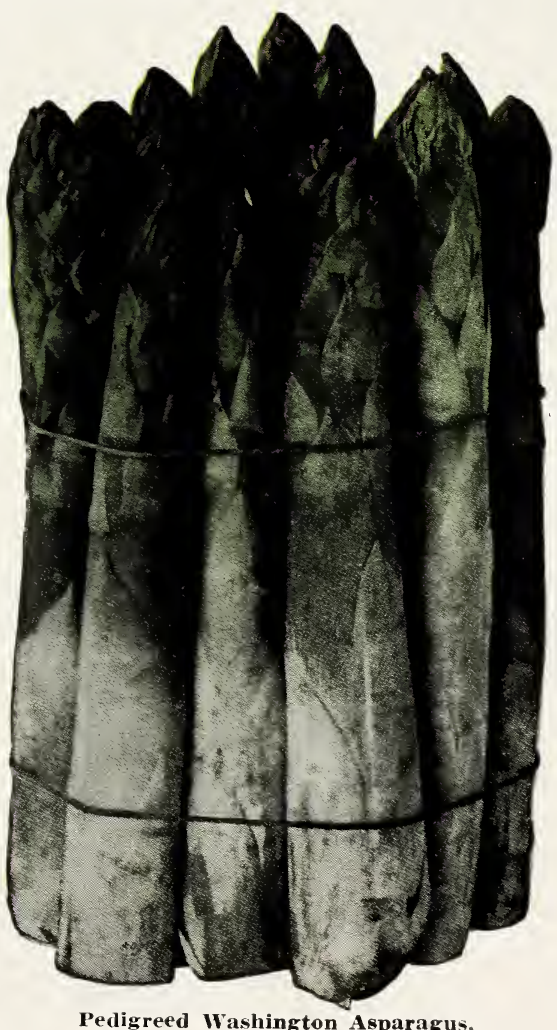




\section{Three Choice Grapes}

\section{Concord}

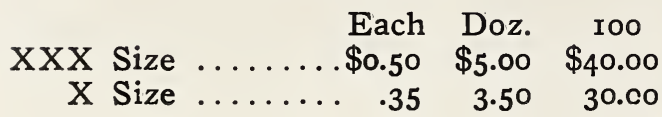

\section{Niagara}

\begin{tabular}{|c|c|c|c|}
\hline $\mathrm{XXX} \mathrm{Siz}$ & & $\begin{array}{l}\text { Each } \\
. \$ 0.60\end{array}$ & $\begin{array}{l}\text { Doz. } \\
\$ 7.00\end{array}$ \\
\hline X Size & & . .40 & 4.00 \\
\hline
\end{tabular}

\section{Catawba}
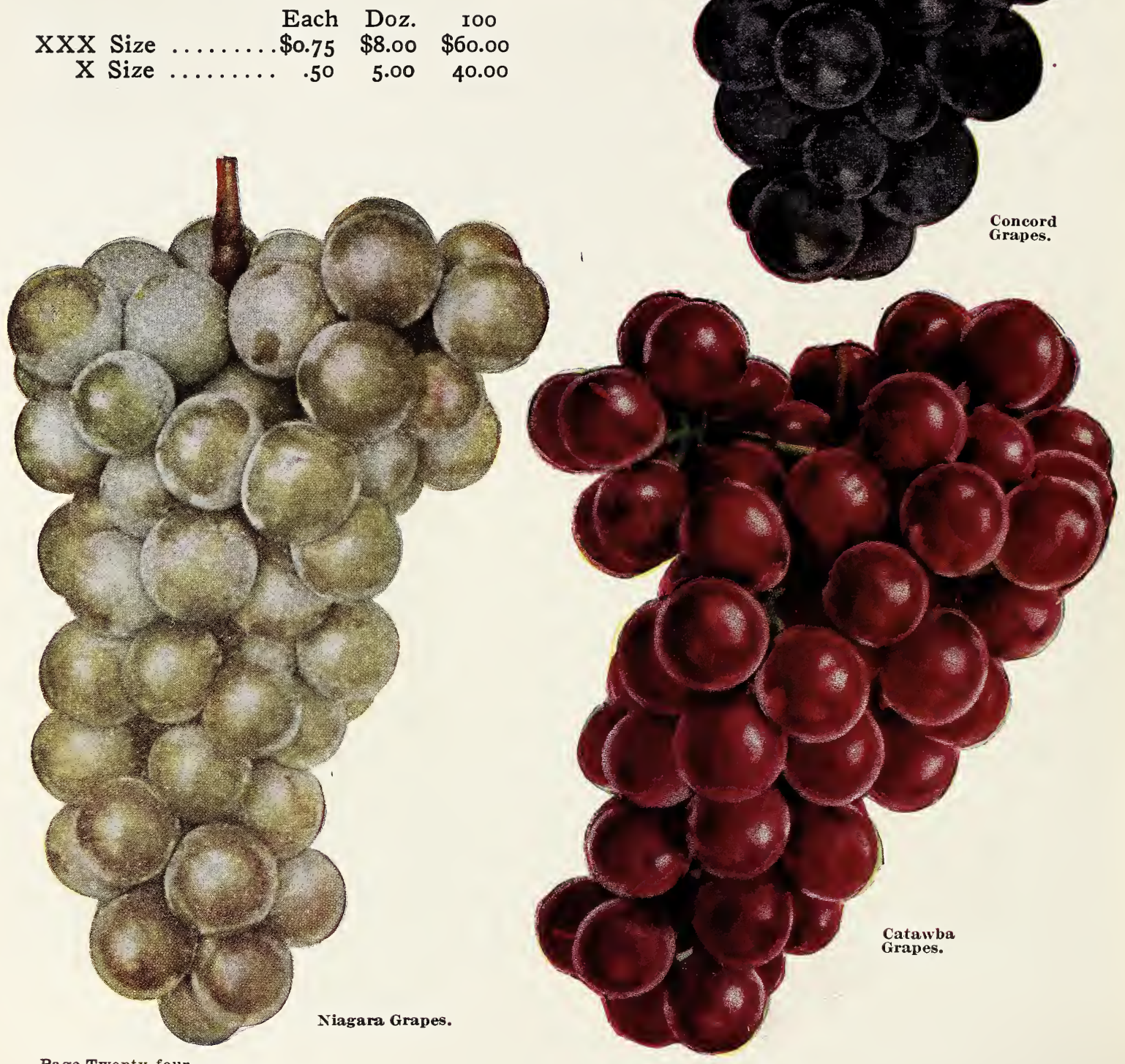


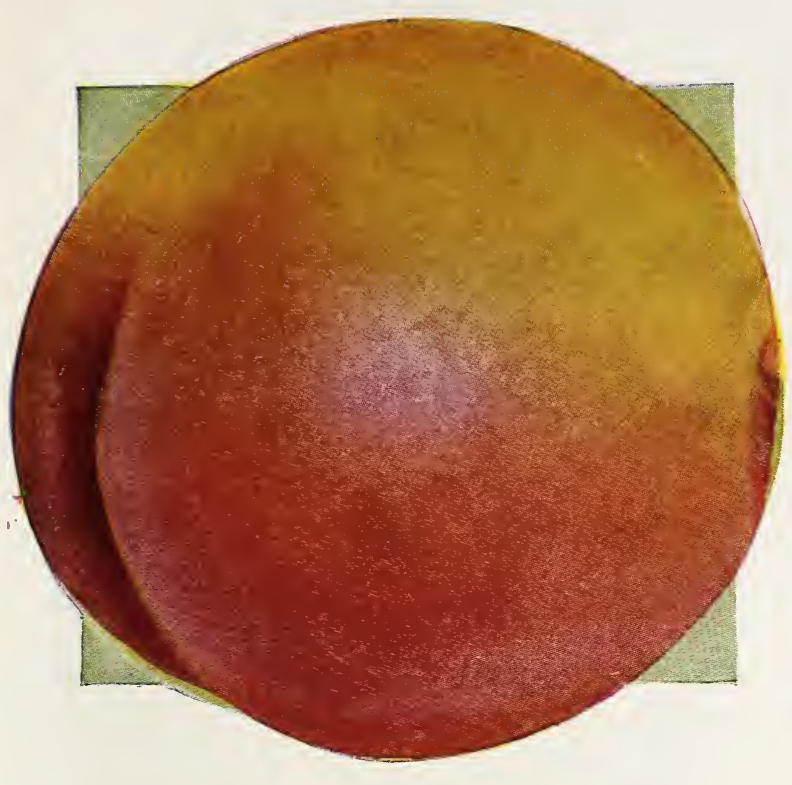

Rochester Peach

One of the earliest yellow freestones. Large, beautiful and of excellent quality. Flesh thick and firm.

Each Doz.

XXX Size (extra large size)..\$r.50 \$17.00

XX Size (large size) ....... I.25 I4.00

X Size (medium size) .... I.00 II.00

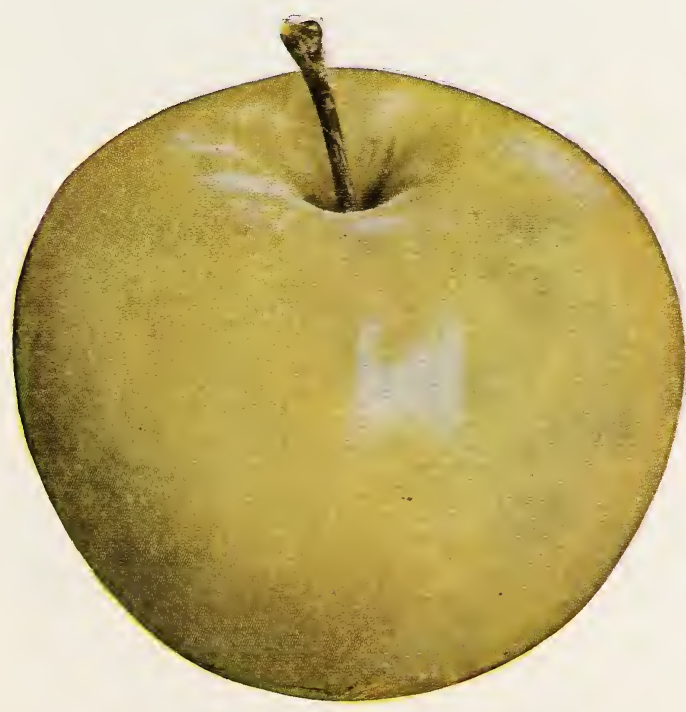

\section{Yellow Transparent Apple}

Fruit of good size and quality. Flesh white, tender, juicy. July and August. Each Doz.

XXX Size (ex. large size) \$2.00 \$23.00

XX Size (large size) .. I.75 20.00

$\begin{array}{lll}X \text { Size (medium size) } & \text { I.25 } & \text { I4.00 }\end{array}$

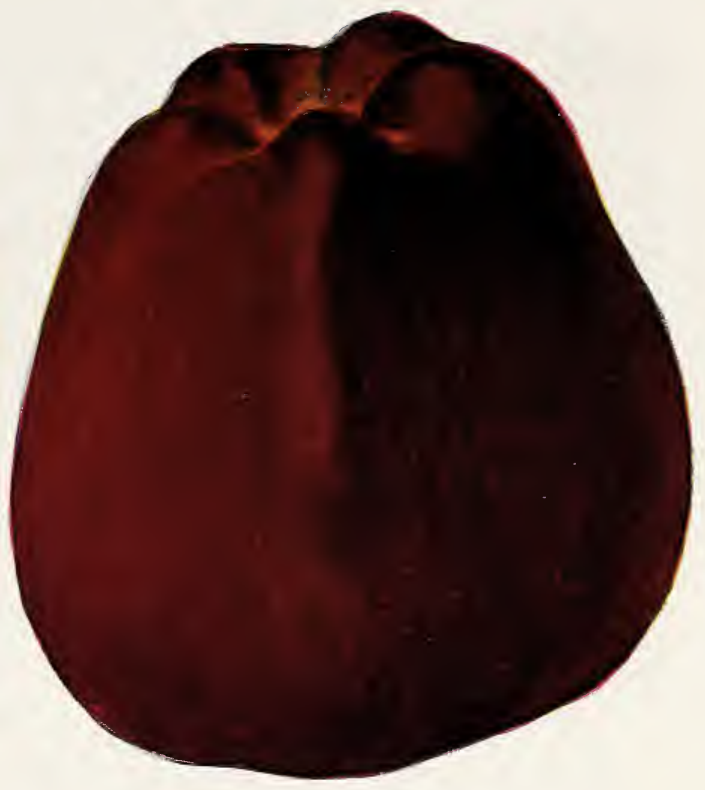

Delicious Apple

One of the best of the good sorts. Flesh white and sweet. A good keeper.

Xxx Each Doz.

XXX Size (extra large size).. \$2.00 \$23.00

XX Size (large size) ...... I.75 20.00

$\mathrm{X}$ Size (medium size) ....

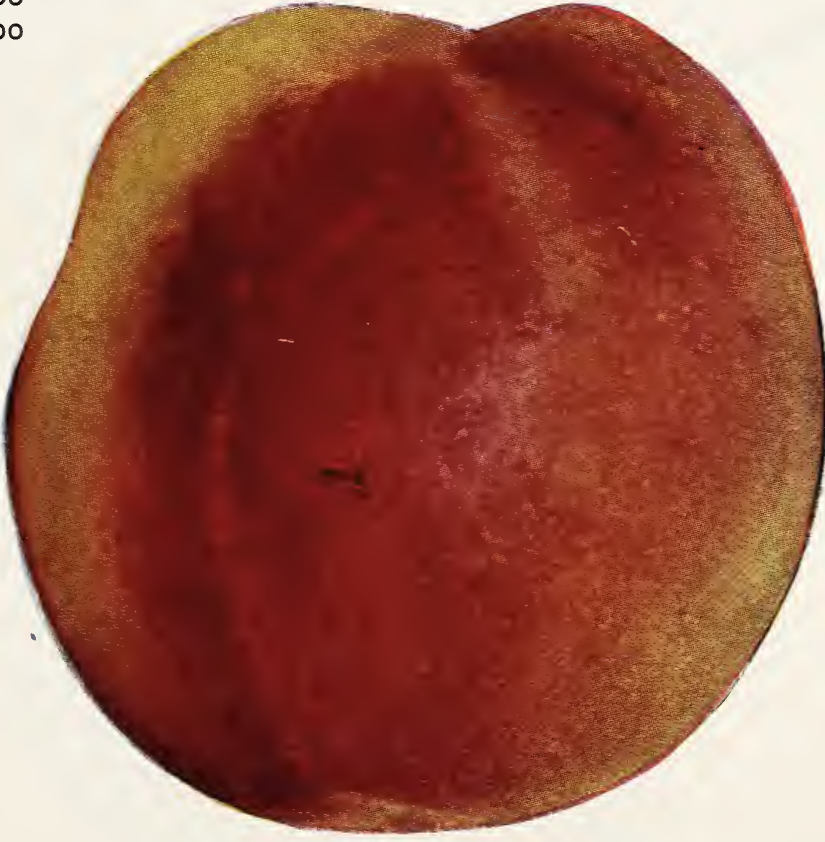

\section{Hale Peach}

One of the finest of all yellow freestones. Excellent flavor. Hale is one of the most popular varieties for home and orchard. Each Doz.

XXX Size (extra large size) ...... \$1.50 \$17.00

XX Size (large size) ............ I.25 I4.00

$\mathrm{X}$ Size (medium size) …....... I.00 II.00 


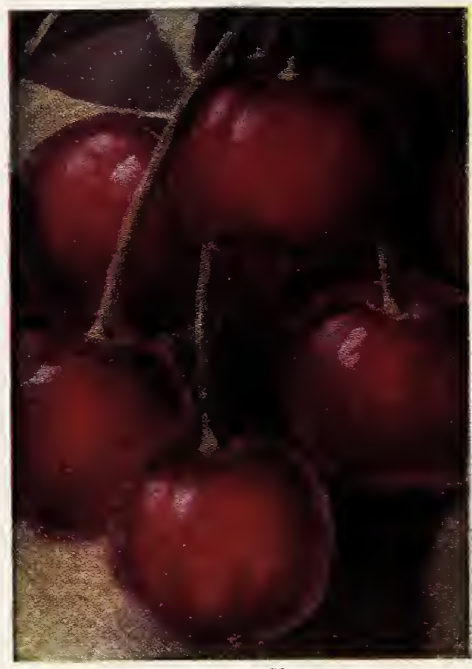

Montmorency Cherry.

\section{Montmorency Cherry}

An unexcelled large sour variety. Just the proper kind for the home garden and canning. Each Doz.

XXX Size (extra large size) . \$2.50 \$29.00 XX Size (large size) ..... 2.00 23.00

X Size (medium size) .... I.50 I7.00

Clapp's Favorite Pear.

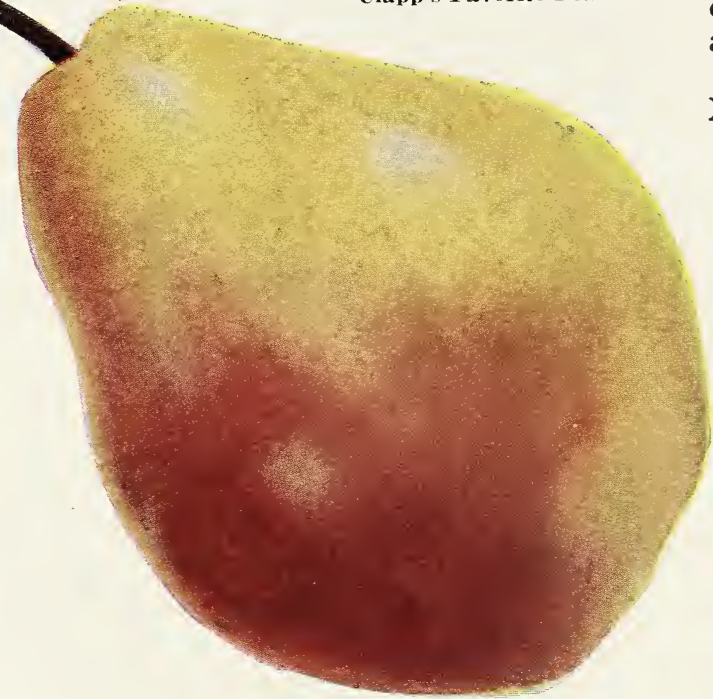

\section{Clapp's Favorite Pear}

Large, showy, fine looking Pear of good quality, profitable for market. Golden yellow with red cheek; melting, juicy, with sweet, delicate flavor. Each Doz.

XXX Size (extra large size) . \$2.50 \$29.00

XX Size (large size) ..... 2.00 23.00

$X$ Size (medium size) ... I.50 I 7.00

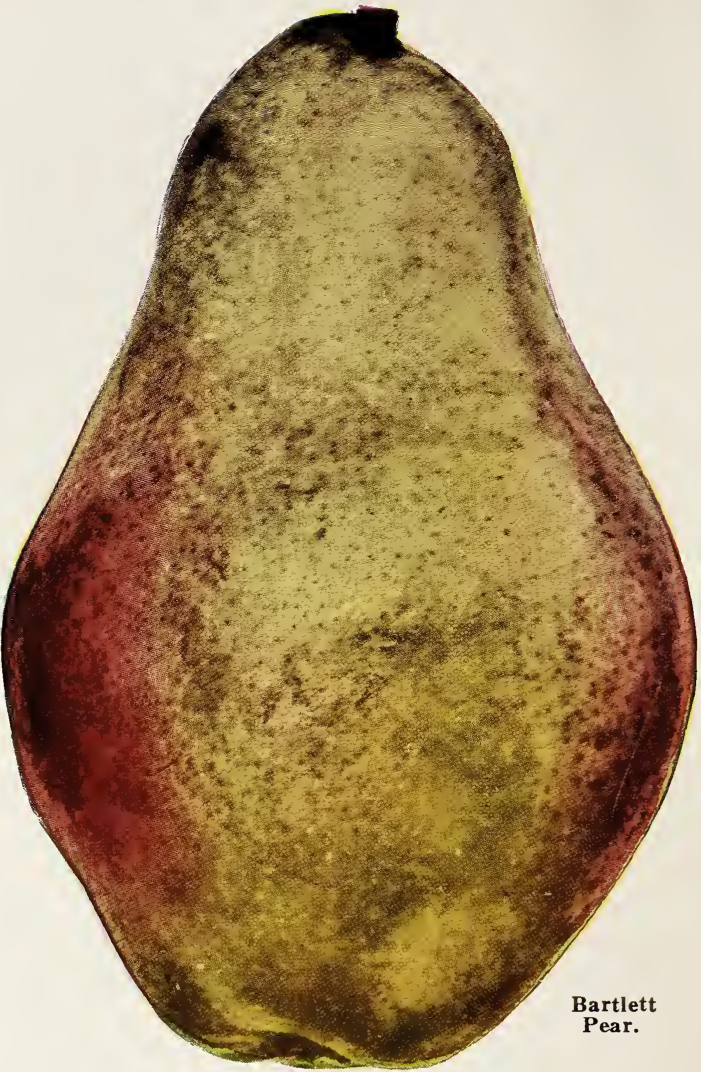

Bartlett Pear

General favorite. Large, beautiful and excellent; yellow, tinged with red; buttery and melting; rich, musky flavor.

Each Doz.

XXX Size (extra large size). .\$2.50 \$29.00

XX Size (large size) ..... $2.00 \quad 23.00$

X Size (medium size) .... I.50 I 7.00

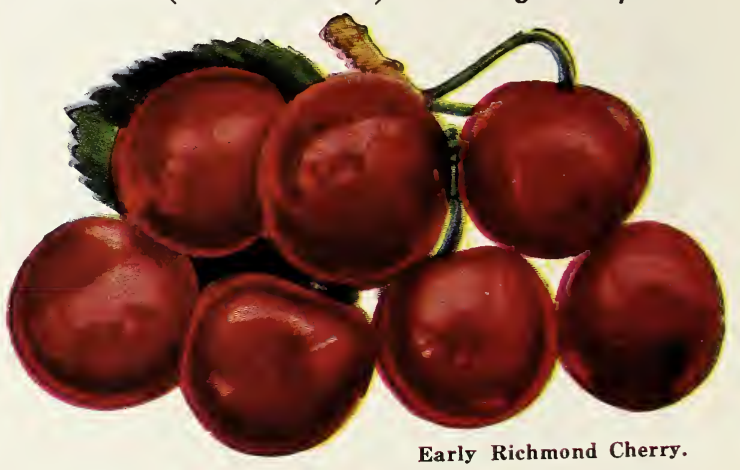

\section{Early Richmond Cherry}

The earliest of sour Cherries. Delicious flavor. Very palatable when eaten from hand. Fine for pies, canning, in fact, is truly a favorite for home use.

Each Doz.

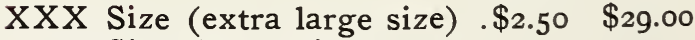

XX Size (large size) ..... $2.00 \quad 23.00$

X Size (medium size) .... I.50 I7.00 


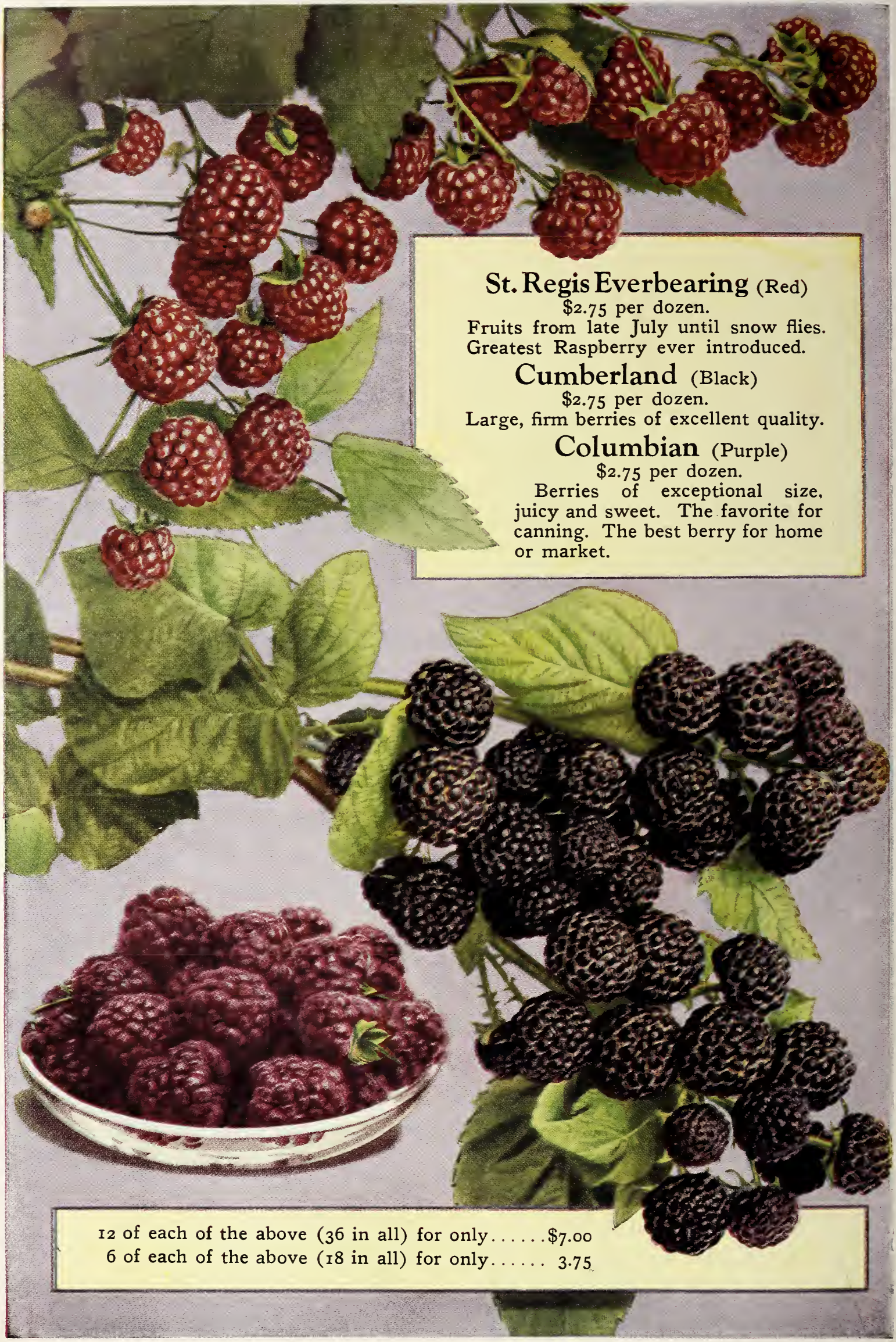

